\title{
THE CHARACTERIZATION AND QUANTITATIVE ANALYSIS OF CLAY MINERALS IN THE ATHABASCA BASIN, SASKATCHEWAN: APPLICATION OF SHORTWAVE INFRARED REFLECTANCE SPECTROSCOPY
}

\author{
GUANGYU ZHANG, KEN WASYLIUK ${ }^{\mathbb{q I}}$ AND YUANMING PAN ${ }^{\S}$ \\ Department of Geological Sciences, University of Saskatchewan, Saskatoon, Saskatchewan S7N 5E2, Canada
}

\begin{abstract}
The application of shortwave infrared (SWIR) reflectance spectroscopy to the characterization of clay minerals in the Athabasca Basin, in Saskatchewan, has been evaluated by detailed examination of 70 mineral separates (20 of kaolinite, 10 of dickite, 19 of illite, 16 of chlorites and 5 of magnesiofoitite). Clay minerals in the Athabasca Basin are widespread in the sandstones and are particularly abundant in alteration haloes associated with unconformity-type U deposits. SEM, TEM, XRD, EMPA, EPR and SWIR analyses confirm that dickite is a major clay mineral in the sandstones. Kaolinite from different geological settings has distinct values of crystallinity (i.e., Hinckley index in the range 0.84 to 1.61 in alteration haloes, 0.45 to 0.7 in the bleached zones of the paleoregolith, and 0.12 to 0.31 in late fractures and cavities). The SWIR reflectance spectroscopy is capable of quantitatively estimating the crystallinity of kaolinite by using a "14SP Index". Attempts to use SWIR reflectance spectroscopy for structural and compositional analysis of Athabasca illite and sudoite were complicated by the common occurrence of impurities in these minerals. Binary and ternary mixtures using well-characterized mineral standards reveal that SWIR reflectance spectroscopy is capable of identifying clay minerals at abundances as low as $1 \mathrm{wt} \%$. Also, numerical relationships between spectral features and the abundances of clay minerals have been established from the muscovite - kaolinite, muscovite - dickite and muscovite - sudoite mixtures, and have been used to improve an empirical SWIR method for quantitative analysis of clay minerals in the Athabasca Basin. The estimated precision and accuracy of the improved empirical method are between 5 to $10 \%$, comparable to those of conventional XRD methods. The detection limits of the SWIR method for samples containing multiple species of clay minerals are approximately $5 \mathrm{wt} \%$ in relative abundance.
\end{abstract}

Keywords: shortwave infrared reflectance spectroscopy, clay minerals, alteration assemblages, uranium deposits, Athabasca Basin, Saskatchewan.

SOMMAIRE

Nous avons évalué l'applicabilité de la spectroscopie par réflectance dans l'infra-rouge à ondes courtes (SWIR) pour caractériser les argiles du bassin d'Athabasca, au Saskatchewan, en utilisant soixante-dix concentrés (20 de kaolinite, 10 de dickite, 19 d'illite, 16 de chlorites et 5 de magnésiofoïtite). Les argiles sont répandues dans les grès du bassin d'Athabasca Basin, et surtout dans les auréoles d'altération associées aux gisements d'uranium localisés près d'une non-conformité. Les analyses par microscopie électronique à balayage et à transmission, par diffraction X, par microsonde électronique et par SWIR confirment que la dickite est une phase majeure dans les grès. La kaolinite provenant de divers contextes géologiques possède des valeurs distinctes de cristallinité (i.e., indice de Hinckley dans l'intervalle de 0.84 à 1.61 dans les auréoles d'altération, de 0.45 à 0.7 dans les zones lessivées du paléorégolithe, et de 0.12 à 0.31 dans les fractures tardives et les cavités. La technique SWIR peut fournir une estimation quantitative de la cristallinité de la kaolinite en utilisant un indice "14SP". En revanche, les essais d'application de la technique pour effectuer une analyse structurale et compositionnelle de l'illite et de la sudoïte dans le bassin d'Athabasca sont compliqués par l'omniprésence d'impuretés dans ces minéraux. Des mélanges binaires et ternaires d'étalons de minéraux bien caractérisés révèlent que la spectroscopie SWIR permet d'identifier les quantités d'argiles aussi faibles que $1 \%$ par poids. De plus, nous avons établi des relations numériques entre certains aspects du spectre et les abondances des argiles à partir des mélanges muscovite - kaolinite, muscovite - dickite et muscovite - sudoïte; nous nous en sommes servis pour améliorer une approche empirique d'évaluation quantitative des proportions des argiles dans les roches du bassin d'Athabasca fondée sur la spectroscopie SWIR. La précision et la justesse des mesures de la méthode améliorée serait entre 5 et $10 \%$, ce qui est comparable à celles des méthodes conventionnelles fondées sur la diffraction X. Le seuil de détection de la méthode SWIR appliquée à des assemblages d'espèces multiples d'argiles serait d'environ 5\% (poids) en termes d'abondance relative.

(Traduit par la Rédaction)

Mots-clés: spectroscopie par réflectance dans l'infra-rouge à ondes courtes (SWIR), argiles, assemblages d'altération, gisements d'uranium, bassin d'Athabasca, Saskatchewan.

II Also of Cameco Corporation, 2121 11th Street West, Saskatoon, Saskatchewan S7M 1J3, Canada.

$\S \quad$ E-mail address: yuanming.pan@usask.ca 


\section{INTRODUCTION}

Many types of ore deposits (e.g., lode gold deposits, porphyry copper-molybdenum-gold deposits, volcanogenic massive sulfide deposits and unconformity-type uranium deposits) are characterized by intensive and extensive hydrothermal alteration, which is commonly an integral part of the ore-forming processes (Barnes 1997, and references therein). Therefore, detailed investigations of alteration assemblages have been a major part of many studies on these types of deposits and have yielded important insights into the ore-forming processes. Equally important, alteration assemblages, which are commonly far more extensive than the orebodies, provide larger and possibly more recognizable targets for exploration. For example, the unconformity-type uranium deposits in the Athabasca Basin, northern Saskatchewan, are typically small in individual orebodies but are surrounded by extensive haloes of altered rocks (Hoeve \& Quirt 1984a, b). Not surprisingly, these alteration haloes form the cornerstone of many exploration programs for new uranium mineralization in the Athabasca Basin. Also, knowledge of the alteration assemblages (e.g., distribution, paragenesis and conditions of formation of the alteration minerals) is of vital importance to a better understanding of the origin of these deposits (Wilson \& Kyser 1987, Percival et al. 1993, Kotzer \& Kyser 1995, Fayek \& Kyser 1997, Kyser et al. 2000).

In this contribution, we report on an application of SWIR reflectance spectroscopy for the characterization and quantitative analysis of clay minerals in alteration assemblages associated with unconformity-type uranium deposits in the Athabasca Basin. Specifically, we investigated a large suite of clay-mineral separates from various geological settings in the Athabasca Basin to evaluate the usefulness of SWIR reflectance spectroscopy in providing such information as chemical composition, crystallinity and paragenesis of clay minerals. Also, Earle (1994) proposed an empirical method for quantitative analysis of clay minerals in the Athabasca Basin by use of the SWIR reflectance spectra. However, the results of that empirical method remain untested, because the proposal was based on the mineral abundances of natural samples that had not been adequately characterized. Also, one major assumption underlying this empirical method is linearity between mineral abundances and spectral features, which has not been evaluated adequately. There are significant discrepancies between the results of this empirical method and the conventional X-ray diffraction (XRD) analysis (e.g., Hoeve \& Quirt 1984a, cf. Brindley 1980, Reynolds 1989). In particular, this empirical method is known to give erroneous results for samples that contain chloritegroup minerals. Therefore, we prepared artificial mixtures by using well-characterized mineral standards to test the assumption of linearity used in the empirical method of Earle (1994) and, where necessary, to obtain new numerical relationships between mineral abundances and spectral features.

\section{Geological Setting}

The Athabasca Basin is filled by red-bed sandstones of the Mesoproterozoic (Helikian) Athabasca Group overlying a crystalline basement (Fig. 1; Ramaekers 1981). The crystalline basement is made up of Archean gneisses and Paleoproterozoic (Aphebian) metasedimentary rocks, which have been metamorphosed to the middle or upper amphibolite facies. The basement is overlain by a paleoregolith, which is several meters deep and is preserved throughout the Athabasca Basin (MacDonald 1985).

The Athabasca Group consists of a 2000-m sequence of mineralogically mature sandstones and conglomerates, interrupted by two marine intercalations (Hoeve \& Quirt 1984a, 1987). The first is represented by the Wolverine Point Formation, at about $1000 \mathrm{~m}$ above the basin floor; the second gave rise to organic-matter-rich shales and stromatolitic dolomites of the Douglas and Carswell formations at the top of the sequence. The sandstones consist predominantly of quartz grains, which are cemented by secondary quartz, hematite and clay minerals. Accessory minerals include apatite, zircon and tourmaline. Studies of the clay minerals and stratigraphy of the Athabasca Basin, coupled with analyses of fluid inclusions in quartz overgrowths, indicate that the sandstones were buried to a maximum depth of 5-7 km and reached $200^{\circ} \mathrm{C}$ (Hoeve \& Quirt 1984a, Kotzer \& Kyser 1995). Rb-Sr isotopic analysis of authigenic illite from an unaltered sandstone yielded an age of $1477 \pm 57 \mathrm{Ma}$, which has been interpreted to represent the timing of the peak diagenesis in this basin (Kotzer \& Kyser 1995).

\section{Mineralization and hydrothermal alteration}

The uranium deposits in the Athabasca Basin are commonly situated at the intersections of the HelikianAphebian unconformity and post-Athabasca faults (Hoeve \& Quirt 1984a, b, Kyser et al. 2000). There is a general consensus that these deposits formed from hydrothermal-diagenetic processes (Hoeve \& Quirt 1984a, b, Kyser et al. 2000). In this model, first proposed by Hoeve \& Quirt (1984a), uranium deposition is considered to have occurred at a stationary redox front, along which diagenetic basinal fluids interacted with fluids derived from the basement. Regional characterization of the fluids by Kyser and coworkers (Wilson \& Kyser 1987, Kotzer \& Kyser 1995, Fayek \& Kyser 1997, Kyser et al. 2000) revealed that the basinal brines were highly oxidizing and largely responsible for transport of uranium, whereas the basement-derived fluids were reducing.

Hydrothermal alteration is one of the most conspicuous features in the Athabasca Basin and results in the 


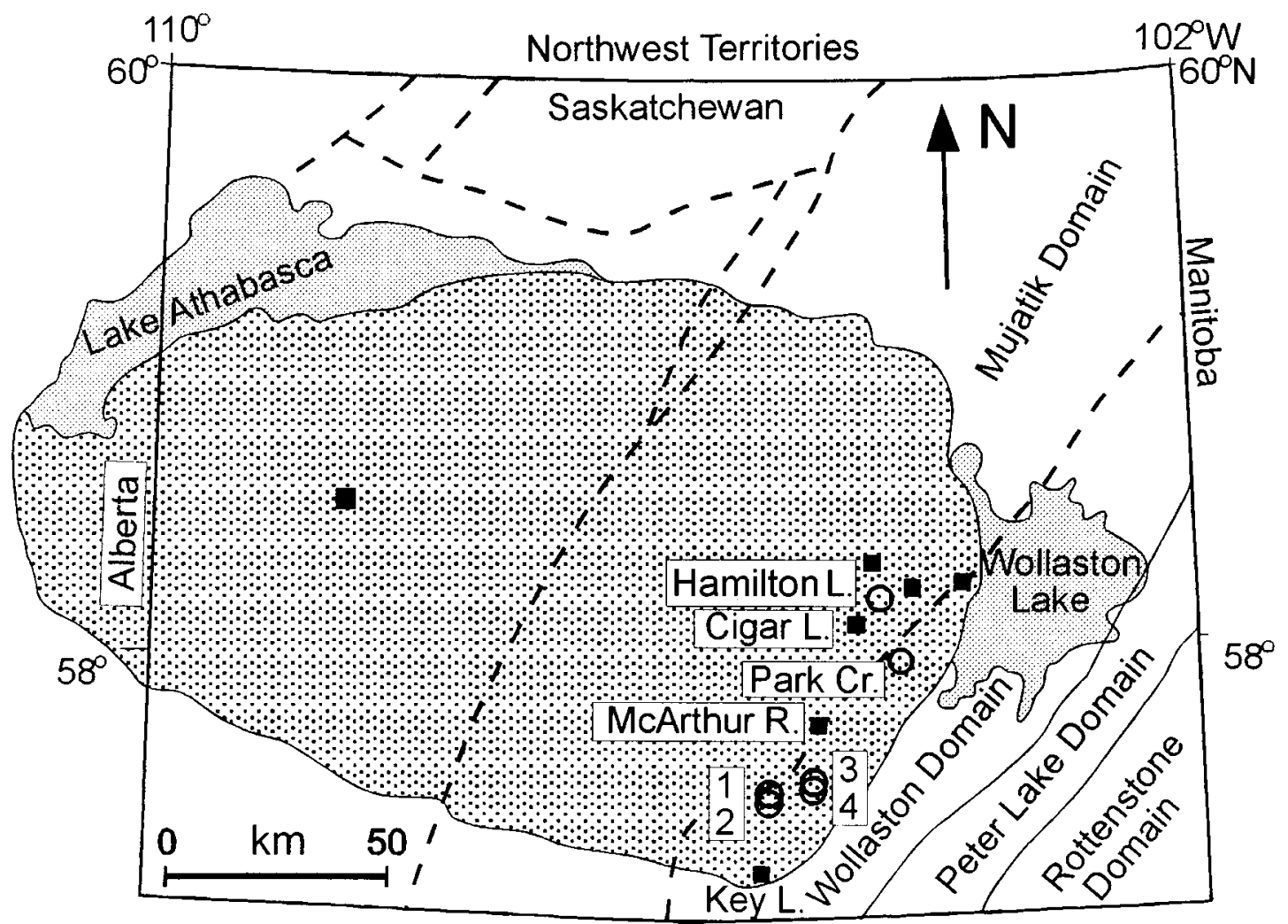

FIG. 1. Geological map of the Athabasca Basin, northern Saskatchewan. Solid squares represent major uranium deposits. Only the deposits sampled (Cigar Lake, Key Lake and McArthur River) are labeled). Open circles represent other sites of sampling (1 Cree Extension Project, 2 Moon Lake Project, 3 Hughes Lake Project, 4 Wheeler River Project; the Cree Zimmer Project surrounds the Key Lake deposit; Hamilton Lake Project, and Park Creek Project; see Table 1).

formation of clay-alteration haloes, bleaching, destruction of graphite, and formation of bitumen (McCready et al. 1999). The alteration halo of the Cigar Lake deposit, for example, extends downward into the basement rocks to about $100 \mathrm{~m}$ below the unconformity and upward about $300 \mathrm{~m}$ into the sandstones (Fouques et al. 1986, Percival et al. 1993). The alteration in the sandstones displays a concentric zonation from top to bottom: 1) bleaching zone reaching to the surface of the sandstones, 2) grey alteration zone with micro-dissemination of iron sulfides, 3) quartz zone, 4) grey alteration zone with strong fracturing and appearance of clay (illite) in the matrix of the sandstones and along fractures, 5) clay alteration in which the clay content gradually increases toward the orebody, 6) massive clay zone, and 7) a hematite-rich clay zone that directly encloses the orebody. Hydrothermal alteration of the basement led to two zones: 1) the zone of total conversion of basement to a clay-dominant assemblage below the richest part of the orebody is characterized by a pale to moder- ate green color and the lack of any original textures, and 2) the partially altered basement, in which original textures are recognizable, contains $\mathrm{Mg}-\mathrm{Fe}$-rich illite and $\mathrm{Mg}-\mathrm{Fe}-$ rich chlorite that formed at the expense of biotite, amphibole, garnet and feldspars. A detailed paragenesis of the clay and other minerals, including those in alteration haloes associated with the unconformity-type uranium deposits in the Athabasca Basin, was given in Fayek \& Kyser (1997).

\section{Samples and Analytical Methods}

\section{Samples and sample preparation}

A total of 70 samples from diverse geological settings (i.e., alteration haloes, sandstones and siltstones away from alteration haloes, basement gneisses and schists, paleoregolith, and late fractures and cavities; Table 1) were investigated in this study. These samples were selected on the basis of available chemical and 
TABLE 1. DESCRIPTION OF SAMPLES ATHABASCA BASIN, SASKATCHEWAN

Kaolinite

\begin{tabular}{|c|c|c|c|c|}
\hline Sample & Location & Lithology & Description & HI \\
\hline DDH753-105 & Deilmann Pit, Key Lake & altered gneiss & alteration halo & 1.16 \\
\hline DDH940-139 & Deilmann Pit, Key Lake & altered gneiss & alteration halo & 1.42 \\
\hline DDH830-64 & Deilmann Pit, Key Lake & sandstone & alteration halo & 1.43 \\
\hline ML7-232 & Moon Lake Project & sandstone & alteration halo & 1.06 \\
\hline ML 7-411.3 & Moon Lake Project & sandstone & alteration halo & 0.84 \\
\hline ML7-412.7 & Moon Lake Project & sandstone & regional & n.d. \\
\hline ML10.6 & Moon Lake Project & sandstone & late fracture & 0.31 \\
\hline ML10-10 & Moon Lake Project & sandstone & late fracture & 0.15 \\
\hline ML10-39 & Moon Lake Project & paleoregolith & bleached zone & 0.70 \\
\hline MAC121-BL-3 & McArthur River & sandstone & late fracture & 0.23 \\
\hline MAC121-BL-7 & McArthur River & sandstone & alteration halo & 0.96 \\
\hline MAC132-BK-5 & McArthur River & paleoregolith & bleached zone & 0.53 \\
\hline MAC178-428.3 & McArthur River & sandstone & late fracture & 0.12 \\
\hline HAM02-38(BH) & Hamilton Lake Project & paleoregolith & bleached zone & 0.69 \\
\hline HAM03-35 & Hamilton Lake Project & paleoregolith & bleached zone & 0.60 \\
\hline HAM05-29(BH) & Hamilton Lake Project & paleoregolith & bleached zone & 0.45 \\
\hline CX13-188.3 & Cree Extension Project & paleoregolith & bleached zone & 0.61 \\
\hline AL19-98 & Cree Zimmer Project & altered gneiss & alteration halo & 1.16 \\
\hline BF $130-90$ & Cree Zimmer Project & sandstone & alteration halo & 1.41 \\
\hline BF $130-60$ & Cree Zimmer Project & sandstone & alteration halo & 1.61 \\
\hline
\end{tabular}

Dickite

\begin{tabular}{llll}
\hline Sample & Location & Lithology & Description \\
& & & \\
HAM01-10 & Hamilton Lake Project & sandstone & regional \\
HAM03-27 & Hamilton Lake Project & sandstone & regional \\
HAM05-23 & Hamilton Lake Project & sandstone & regional \\
HAM7D-05-03 & Hamilton Lake Project & sandstone & regional \\
PK15-81 & Park Creek Project & sandstone & regional \\
PK16-104 & Park Creek Project & sandstone & regional \\
PK16-124 & Park Creek Project & sandstone & regional \\
PK19-117 & Park Creek Project & sandstone & regional \\
PK25-70 & Park Creek Project & sandstone & regional \\
MAC121-424.6 & McArthur River & siltstone & regional \\
& & & \\
\hline
\end{tabular}

Illite

\begin{tabular}{lllll} 
Sample & Location & Lithology & Description & KI \\
& & & & \\
DDH1988-384 & Deilmann Pit, Key Lake & altered gneiss & alteration halo & 1.63 \\
DDH2217-84 & Deilmann Pit, Key Lake & sandstone & alteration halo & 0.75 \\
DDH2217-92 & Deilmann Pit, Key Lake & sandstone & alteration halo & 0.58 \\
DDH2217-102 & Deilmann Pit, Key Lake & sandstone & alteration halo & 0.77 \\
DDH2217-313 & Deilmann Pit, Key Lake & altered gneiss & alteration halo & 1.67 \\
WDG1-8-414.3 & Cigar Lake & sandstone & alteration halo & 0.75 \\
WDG1-44-270.8 & Cigar Lake & sandstone & alteration halo & 0.85 \\
WDG1-46-309 & Cigar Lake & sandstone & alteration halo & 0.87 \\
WDG1-46-411 & Cigar Lake & sandstone & alteration halo & 0.76 \\
WDG1-175- & Cigar Lake & sandstone & alteration halo & 0.91 \\
477.8 & & & & \\
WDG17-391.1 & Cigar Lake & sandstone & alteration halo & 0.79 \\
WDG17-401 & Cigar Lake & sandstone & alteration halo & 0.77 \\
WDG17-411.5 & Cigar Lake & sandstone & alteration halo & 0.77 \\
WDG22-407 & Cigar Lake & sandstone & alteration halo & 0.83 \\
WDG74-432 & Cigar Lake & altered gneiss & alteration halo & 0.91 \\
WDG99-410 & Cigar Lake & sandstone & alteration halo & 0.92 \\
WDG165-474.5 & Cigar Lake & sandstone & alteration halo & 1.00 \\
WDG184-424 & Cigar Lake & sandstone & alteration halo & 0.77 \\
WDG1136-390 & Cigar Lake & sandstone & alteration halo & 0.92 \\
& & & & \\
\hline
\end{tabular}

TABLE 1 (continued). DESCRIPTION OF SAMPLES ATHABASCA BASIN, SASKATCHEWAN

Chlorite-group minerals

$\begin{array}{lll}\text { Sample Location Lithology Description } & \end{array}$

DDH753-248 Deilmann Pit, Key Lake altered gneiss alteration halo DDH753-353 Deilmann Pit, Key Lake altered gneiss alteration halo DDH766-538 Deilmann Pit, Key Lake altered gneiss alteration halo DDH783-272 Deilmann Pit, Key Lake altered gneiss alteration halo DDH930-292- Deilmann Pit, Key Lake altered gneiss alteration halo 303

DDH-940-307 Deilmann Pit, Key Lake altered gneiss alteration halo DDH2033-587* Deilmann Pit, Key Lake altered gneiss alteration halo WDG1-140- Cigar Lake sandstone alteration halo

413.3

WDG1-185.

441.2

minetalized

ML10-34 Moon Lake Project sandstone mineralized

MAC204-227 McArthur River sandstone mineralized

MAC204-605.7 McArthur River altered gneiss alteration halo

ZK13-4915 Wheeler River Project sandstone regional

ZQ20-300.7 Wheeler River Project altered gneiss alteration halo

\begin{tabular}{lllll}
\hline \multicolumn{5}{c}{ Magnesiofoitite } \\
\hline Sample & Location & Lithology & Description & 8D \\
& & & & $(\%)$ \\
DDH753-117 & Deilmann Pit, Key Lake & sandstone & late fracture & \\
MAC110-443 & McArthur River & sandstone & late fracture & -80 \\
MAC110-444 & McArthur River & sandstone & breccia & -89 \\
MAC110-453 & McArthur River & sandstone & breccia & -92 \\
MAC121-345 & McArthur River & sandstone & breccia & \\
& & & & \\
\hline
\end{tabular}

HI: Hinckley index for kaolinite ( $c f$. Hinckley 1963); Kr: Kübler index for illite ( $c f$. Kübler 1964). * a clinochlore-bearing sample. The $\delta \mathrm{D}$ values of the tourmaline separates relative to Vienna Standard Mean Ocean Water. n.d.: not determined.

XRD data (e.g., Hoeve \& Quirt 1984a, Wilson \& Kyser 1987, Kotzer \& Kyser 1995, and unpublished reports of the Cameco Corporation) and preliminary SWIR reflectance spectroscopic measurements indicating that each contains essentially a single clay mineral. Clay-mineral separation for these samples followed the method of Jambor \& Delabio (1978). In particular, all samples were treated by light hand-crushing in order to minimize possible structural damages and grain-size reduction. Also, we used the method of Mehra \& Jackson (1960) to remove the iron oxide impurities in three kaolinite separates selected for electron paramagnetic resonance (EPR) spectroscopic analysis.

\section{Analytical methods}

All samples, except for some clay-rich powder samples that were mounted in Pyrex plugs, were sectioned and polished for petrographic observation and back-scattered electron imaging on a JEOL JXA-8600 electron microprobe at the Department of Geological 
Sciences, University of Saskatchewan (U of S). Morphological examination of some samples was also made on fresh surfaces or on separates using a JEOL JSM840A scanning electron microscope (SEM) at the Department of Geological Sciences and on suspended powder using a Philips CM10 transmission electron microscope (TEM) at the Department of Biology, U of S. Chemical analyses of minerals were carried out on polished thin sections or Pyrex plugs with an electron microprobe equipped with three wavelength-dispersion and one energy-dispersion spectrometers. Operating conditions included $15 \mathrm{kV}$ accelerating voltage, $10 \mathrm{nA}$ beam current, and a beam 0.5 to $2 \mu \mathrm{m}$ in diameter; the analysis was made with reference to mineral standards.

Oriented mounts of clay-mineral separates for XRD analysis were obtained by precipitation on glass slides, whereas randomly oriented mounts were prepared following the method of Środon (1980). XRD analyses of most clay-mineral separates were performed from $3^{\circ}$ to $65^{\circ} 2 \theta$ and a scan speed of $0.2^{\circ} 2 \theta$ /minute on a Rigaku Rotaflex X-ray diffractometer using Ni-filtered $\mathrm{CuK \alpha}$ radiation at the Department of Geological Sciences. A few samples of sudoite were analyzed on a Rigaku Rotaflex X-ray diffractometer using $\mathrm{Fe} K \alpha$ radiation at the Department of Soil Science, U of S. The crystallinity of kaolinite (Hinckley 1963) was obtained by analyzing randomly oriented mounts of separates from $18^{\circ}$ to $30^{\circ} 2 \theta$, using $\mathrm{Cu} K \alpha$ radiation and a scan speed of $0.2^{\circ}$ 20/minute on a Philips 42273 X-ray diffractometer at the Saskatchewan Research Council. Oriented mounts of illite were also subject to ethylene glycol treatment to test for the possible presence of smectite or mixedlayer clay minerals. The crystallinity of illite (Kübler 1964) was determined by analysis of oriented mounts from $5^{\circ}$ to $10^{\circ} 2 \theta$, using $\mathrm{Cu} K \alpha$ radiation and a scan speed of $0.2^{\circ} 2 \theta$ /minute on the Rigaku Rotaflex X-ray diffractometer.

The SWIR reflectance spectrometer used in this study, a portable Integrated Spectronics PIMA-II instrument, measures reflectance at wavelengths from 1300 to $2500 \mathrm{~nm}$, with a sampling interval of $2 \mathrm{~nm}$ (i.e., 601 channels of data) and a nominal spectral resolution of 6 to $10 \mathrm{~nm}$. All spectral features in this range of wavelengths are related to vibrational processes that occur in hydroxyl-bearing minerals, carbonates, sulfates and phosphates (Farmer 1974, Hunt \& Ashley 1979, McMillan \& Hofmeister 1988). The PIMA-II employs a halogen light-source and is equipped with a plastic target for calibration. SWIR spectra are collected by placing samples against a sensor window, which contains a $2 \times 10 \mathrm{~mm}$ rectangular optical port. Analysis of a series of calibration spectra revealed that PIMA-II is subject to instrument noise, which could affect the spectral data of samples and therefore must be minimized or corrected for. In this study, we used polytetrafluoroethylene as a standard, first to minimize the instrument noise by optimizing the operating conditions, and then to correct for the small residual noise during data analy- sis. Also, we used well-characterized kaolinite and muscovite, from the U of S XRD collection, as standards to evaluate the effects of sample size, sample orientation and grain size on the SWIR spectra. Our analyses of these standards showed that there are no significant differences in the measured reflectance intensity for sample sizes from 0.5 to $5 \mathrm{~g}$, but preferred orientation and grain size have significant influences on the SWIR spectra (Zhang 2000). However, the clay minerals in the rock samples of this study generally do not show any preferred orientation; care was taken to minimize preferred orientation during the analysis of clay-mineral separates. Also, grain size was unlikely a major factor for this study on clay minerals. SWIR measurements of rock samples in the field were made directly on fresh surfaces, although some samples were dried in a microwave oven for up to 2 minutes. Clay-mineral separates were first air-dried and then gently packed into petri dishes $(1.5 \mathrm{~cm}$ in diameter) to obtain randomly oriented amounts for SWIR measurements. The SWIR spectra were either examined by use of the PIMAVIEW software supplied by the manufacturer or exported as binary files for analysis (noise correction, spectral deconvolution, etc.) on a commercial software package (i.e., GRAMS/32 of the Galactic Industries Corporation). The baseline correction for the SWIR spectra was made, where needed, by using the Hull Quotient method included in the PIMAVIEW software.

Other analytical methods used in this study included Fourier-transform infrared (FTIR) absorption spectroscopy on a BIO-RAD FTS-40 spectrometer and EPR spectroscopy on a Bruker ESP300 spectrometer at the Department of Chemistry, and hydrogen isotopic analysis on a VG 602 mass spectrometer at the Department of Geological Sciences.

\section{Artificial mixtures}

Artificial mixtures were made using well-characterized mineral standards (i.e., quartz, kaolinite, dickite and muscovite) and mineral separates from the Athabasca Basin (i.e., sudoite and tourmaline). The quartz standard was a large single crystal $(2 \times 2 \times 5 \mathrm{~cm})$ from an unknown locality. XRD and SEM analyses showed that the kaolinite standard from Montana has a purity of approximately $99 \%$, with quartz and iron oxides as the trace impurities. The dickite standard from Georgia is also approximately $99 \%$ pure. A $2 M_{1}$ muscovite was used as an analogue for illite (see below for justification). A sudoite separate from sample ZQ20-300.7 was chosen because it has one of the highest purities (approximately $95 \%$ sudoite and 5\% illite) and is relatively abundant ( $10 \mathrm{~g}$ in total). A tourmaline separate from sample MAC110-444.2 (magnesiofoitite, see below) was selected for similar reasons (e.g., $~ 98 \%$ pure).

Eight series of binary and ternary mixtures were made to represent the most common mineral assemblages in the Athabasca Basin: 1) quartz - kaolinite, 2) 

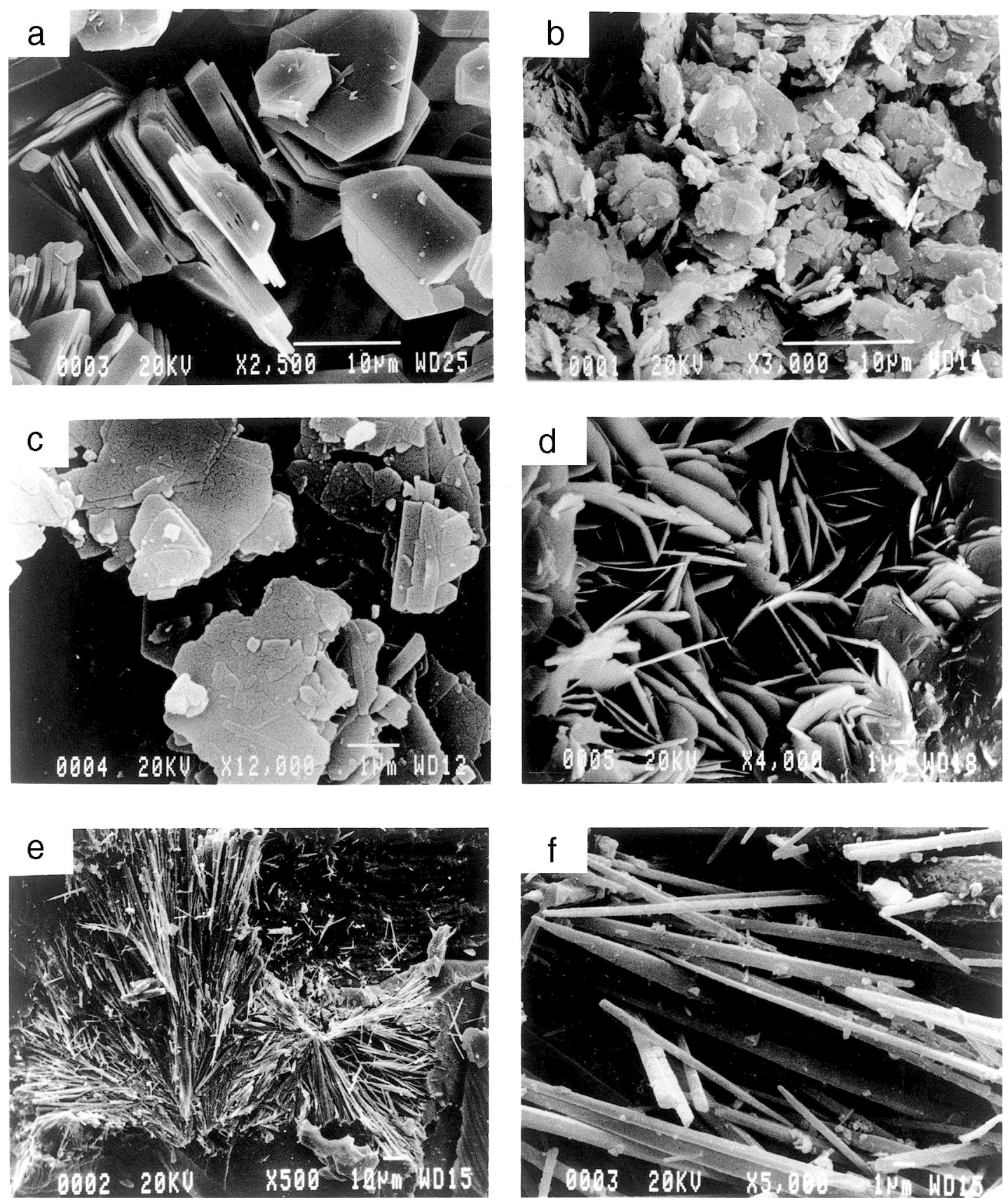

FIG. 2. SEM photomicrographs of the Athabasca clay minerals: a) euhedral dickite from a regional sandstone (sample PK1581), b) subhedral kaolinite from an alteration halo (sample MAC121-BL-7), c) illite from an alteration halo (sample WDG146-411), d) sudoite from an alteration halo (sample MAC204-605.7), e) aggregates of magnesiofoitite from the McArthur River deposit, and f) acicular crystals of magnesiofoitite. 
quartz - dickite, 3) kaolinite - dickite, 4) kaolinite muscovite, 5) dickite - muscovite, 6) sudoite - muscovite, 7) muscovite - kaolinite - sudoite, and 8) muscovite - kaolinite - tourmaline. Nine quartz-kaolinite mixtures (1 to $2 \mathrm{~g}$ each) were made for the following weight proportions (quartz/kaolinite): 100/0, 99/1, 97/ $3,95 / 5,93 / 7,91 / 9,89 / 11,87 / 13$ and $85 / 15$. The quartzdickite mixtures were made for weight proportions of 100/0, 99/1, 98/2, 97/3, 96/4, 95/5, 94/6, 93/7, 92/8, 91/ 9 , and $90 / 10$. The rest of the binary mixtures were made for weight proportions of 100/0, 98/2, 95/5, 90/10, 80/

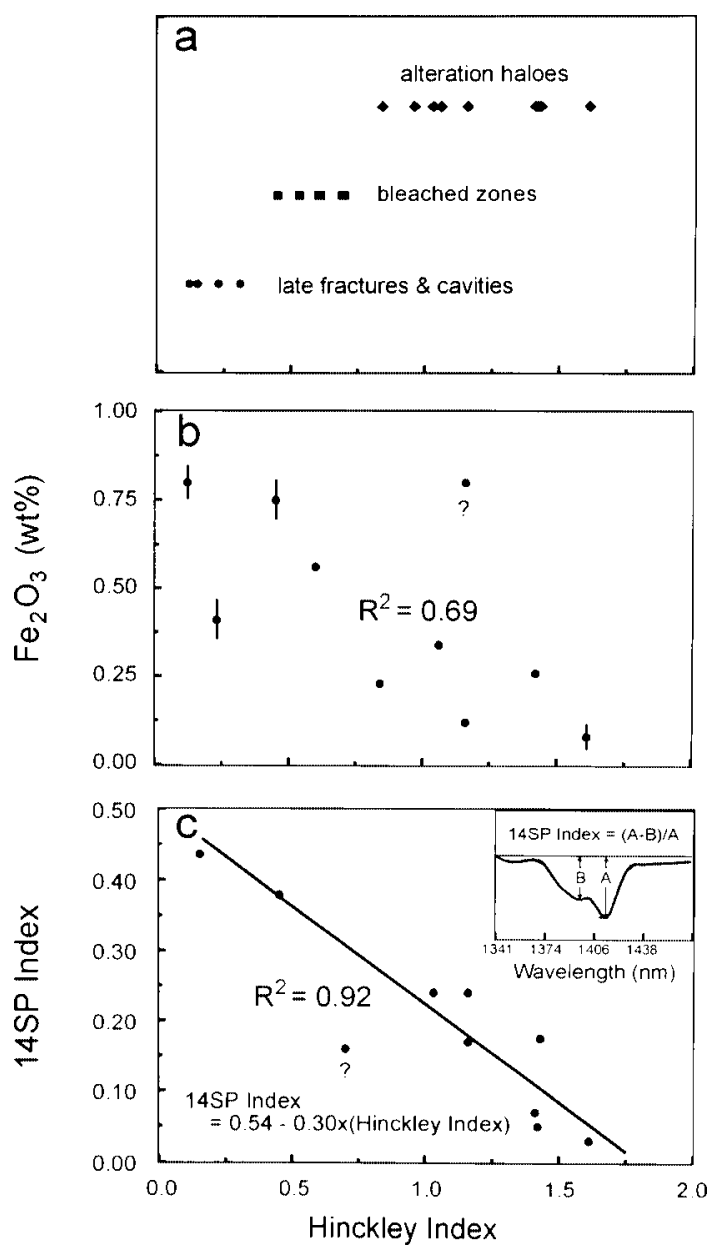

FIG. 3. Hinckley index of the Athabasca kaolinite. a) Correlation with geological settings. b) Correlation with the total iron contents expressed as $\mathrm{Fe}_{2} \mathrm{O}_{3}$ [error bars represent the standard deviation $(1 \sigma)$ of results of between 3 and 8 analyses; the correlation coefficient was calculated without the anomalous sample (labeled "?")]. c) Correlation with the "14SP Index" (the insert illustrates the definition of the 14SP index; the solid line was obtained from linear regression without the anomalous sample).
20, 70/30, 50/50, 30/70, 20/80, 10/90, 5/95, 2/98 and $0 /$ 100 . The ternary mixtures were both made for weight proportions of 100/0/0, 98/1/1, 95/2.5/2.5, 90/5/5, 80/ 10/10, 70/15/15, 60/20/20, 50/25/25, 40/30/30, 30/35/ $35,20 / 40 / 40,10 / 45 / 45,5 / 47.5 / 47.5,2 / 49 / 49$ and $0 / 50 /$ 50 . These mixtures were shaken in vials $(\sim 2.5 \mathrm{~cm}$ in diameter) to ensure homogeneity and random orientation; these were then placed against the sensor window for SWIR measurements.

\section{Characterization of Clay Minerals}

\section{Kaolinite-group minerals}

Kaolinite-group minerals, including dickite and kaolinite (Figs. 2a, b), are widespread in the Athabasca Basin, and particularly abundant in alteration haloes associated with uranium deposits. Previous investigators (e.g., Wilson \& Kyser 1987, Kotzer \& Kyser 1995) established three generations of kaolinite-group minerals: K1: diagenetic and regionally developed in sandstones away from alteration haloes, K2: in alteration haloes, and K3: in late cavities and fractures. SWIR reflectance spectroscopic analysis by Earle et al. (1996) suggested that dickite, not kaolinite, is the characteristic and widespread clay mineral in the sandstones. This observation has been confirmed in this study on the basis of combined SEM, TEM, XRD, EPR and SWIR analyses. For example, these two minerals are distinct in XRD patterns in the range from 70 to $73^{\circ} 2 \theta(\mathrm{CuK \alpha}$ radiation; cf. Rusinova et al. 1974, Zotov et al. 1998) and in EPR spectra at $\mathrm{g} \approx 4$ ( $c f$. Brindley et al. 1986, Zhang 2000). We also show that the $\mathrm{K} 1$ fraction in the sandstones is dickite. Kaolinite is particularly common in alteration haloes and also occurs in the bleached zones of the paleoregolith and in late fractures and cavities (Table 1). Electron-microprobe analyses reveal that the Athabasca kaolinite has somewhat higher $\mathrm{Fe}_{2} \mathrm{O}_{3}$ contents than dickite ( 0.08 to $0.79 \mathrm{wt} \%$ and 0.06 to $0.12 \mathrm{wt} \%$, respectively; see also Mosser et al. 1996).

The XRD analyses show that the crystallinity of the Athabasca kaolinite varies widely (Hinckley index in the range 0.12 to 1.61 ; Table 1 ). More importantly, this variation is closely related to geological settings: 0.12 to 0.31 for kaolinite in late fractures and cavities, 0.45 to 0.7 for kaolinite in the bleached zones, and 0.84 to 1.61 for kaolinite in alteration haloes (Fig. 3a). The Hinckley index has been used widely to represent the structural disorder of kaolinite (Brindley et al. 1986, Artioli et al. 1995) and has been linked variably to vacancy displacements within the sheet of octahedra (Plançon \& Tchoubar 1977) or substitutions of $\mathrm{Fe}^{3+}$ impurities in the octahedral sites (e.g., Brindley et al. 1986, Delineau et al. 1994, Mosser et al. 1996, Gaite et al. 1997). The weak negative correlation between the total iron content as $\mathrm{Fe}_{2} \mathrm{O}_{3}$ and the Hinckley index in the Athabasca kaolinite (Fig. 3b) appears to support the latter model. 


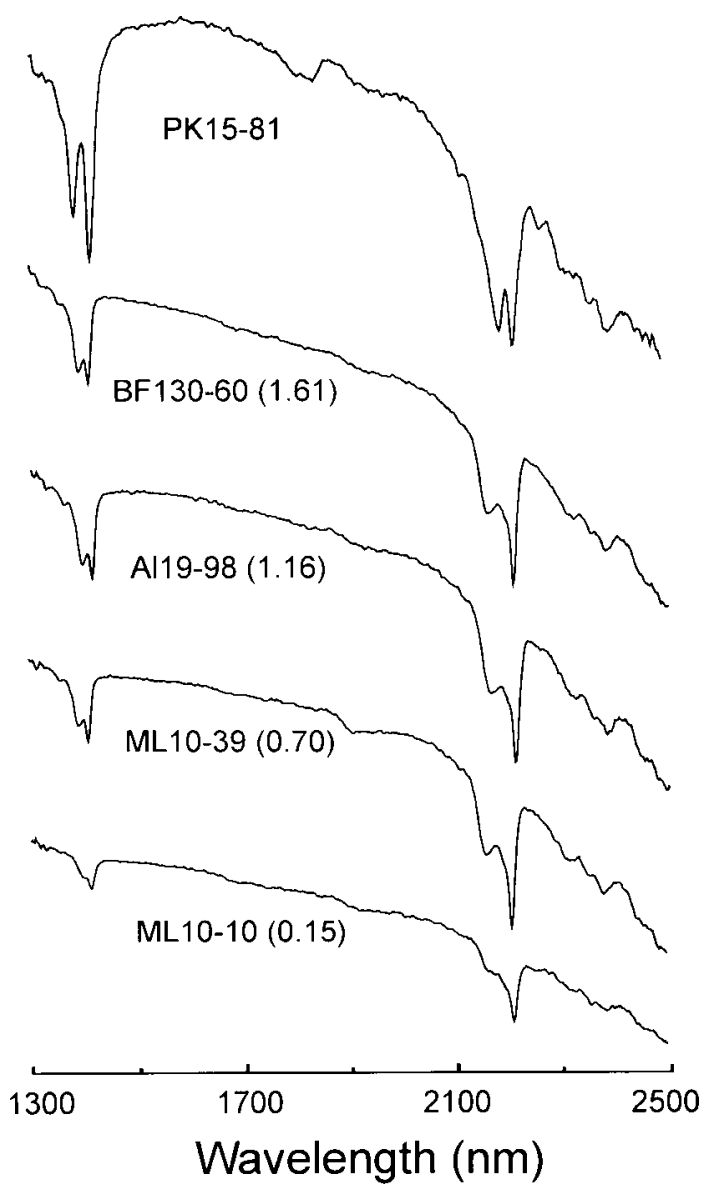

FIG. 4. Comparison of the SWIR spectra of Athabasca dickite (sample PK15-81) and kaolinite (samples BF130-60, AL19-98, ML10-39 and ML10-10). Note that the morphology of the $1400 \mathrm{~nm}$ doublet of the kaolinite spectra changes systematically with the Hinckley indices, shown in parentheses.

Figure 4 shows that the SWIR spectra of kaolinite and dickite are distinct at the 1400 and $2200 \mathrm{~nm}$ regions; these regions have been assigned to the first harmonic of inner-surface $\mathrm{OH}$ stretching fundamental vibration modes and the combination of outer-surface $\mathrm{OH}$ stretching overtone and $\mathrm{Al}-\mathrm{OH}$ bending, respectively (Brindley et al. 1986, Johnston et al. 1998). It is noteworthy that the morphology of the $1400 \mathrm{~nm}$ doublet of the kaolinite spectra changes systematically with crystallinity (Fig. 4), as is also evident by a linear correlation between the "14SP Index" and the Hinckley index. Here, the "14SP Index" is defined as (A - B)/A, where $\mathrm{A}$ and $\mathrm{B}$ correspond to the depths of the $1400 \mathrm{~nm}$ doublet on the kaolinite spectra after the baseline correction (see insert in Fig. 3c). Similarly, Brindley et al.
(1986) showed that there are systematic relationships between the Hinckley index of kaolinite and the FTIR absorption features (i.e., frequency and half-width of the hydroxyl-stretching band). It should be emphasized that infrared spectra are influenced mainly by short-range order and are relatively insensitive to long-range order in minerals, whereas XRD patterns are more sensitive to long-range order (e.g., Gaite et al. 1997). Therefore, information about the kaolinite structure derived from infrared spectroscopy is not expected to be identical to that from XRD (Fig. 3c).

\section{Illite}

Illite is also widely distributed in the Athabasca Basin and is particularly common in both the alteration haloes and the regional sandstones. Hoeve \& Quirt (1984a) and Percival et al. (1993) showed that the Athabasca illite exhibits wide variations in both polytypism and crystallinity. In particular, Hoeve \& Quirt (1984a) showed that illite in the alteration haloes is usually the polytype $3 T$, whereas $1 M$ and $2 M_{1}$

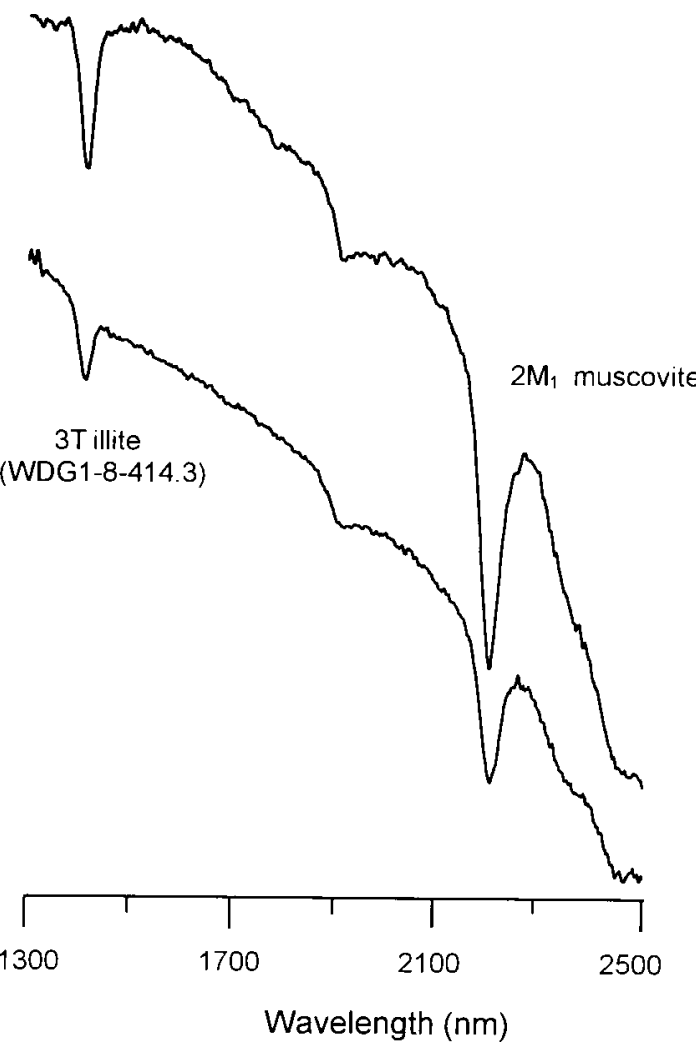

FIG. 5. Comparison of the SWIR spectra of an Athabasca $3 T$ illite (sample WDG1-8-414.3) and a $2 M_{1}$ muscovite from the U of S XRD standard collection. 
TABLE 2. COMPOSITIONS OF SELECTED MINERALS, ATHABASCA BASIN, SASKATCHEWAN

\begin{tabular}{|c|c|c|c|c|c|c|c|c|}
\hline \multirow[b]{2}{*}{ Sample } & \multicolumn{2}{|c|}{ Kaolinite } & \multicolumn{2}{|c|}{ Dickite } & \multicolumn{4}{|c|}{ Illite } \\
\hline & $\begin{array}{c}\text { ML7- } \\
232\end{array}$ & $\begin{array}{c}\mathrm{MAC} 121 \\
-\mathrm{BL}-3\end{array}$ & $\begin{array}{l}\text { PK19 } \\
-117\end{array}$ & $\begin{array}{c}\text { PK25 } \\
-70\end{array}$ & $\begin{array}{l}\text { WDG } \\
17-401\end{array}$ & $\begin{array}{c}\text { WDG } \\
22-407\end{array}$ & $\begin{array}{c}\text { DDH } \\
2217-84\end{array}$ & $\begin{array}{l}\text { WDG } \\
74-432\end{array}$ \\
\hline $\mathrm{SiO}_{2} \mathrm{wt}^{\circ} \%$ & 47.5 & 46.9 & 46.9 & 47.3 & 47.4 & 48.9 & 46.6 & 47.7 \\
\hline $\mathrm{TiO}_{2}$ & 0.01 & 0 & 0 & 0.01 & 0.02 & 0.21 & 0.10 & 0.02 \\
\hline $\mathrm{Al}_{2} \mathrm{O}_{3}$ & 38.6 & 38.4 & 39.1 & 38.8 & 33.6 & 34.8 & 31.7 & 34.4 \\
\hline $\mathrm{Cr}_{2} \mathrm{O}_{3}$ & 0.02 & 0.02 & 0.01 & 0.01 & 0 & 0.01 & 0.02 & 0.01 \\
\hline $\mathrm{Fe}_{2} \mathrm{O}_{3} \dagger$ & 0.34 & 0.41 & 0.06 & 0.07 & & & & \\
\hline FeOtt & & & & & 0.59 & 1.95 & 0.76 & 0.64 \\
\hline $\mathrm{MgO}$ & 0.14 & 0.24 & 0.05 & 0.05 & 1.07 & 0.74 & 0.83 & 0.67 \\
\hline $\mathrm{MnO}$ & 0 & 0.01 & 0 & 0.03 & 0.01 & 0.05 & 0.02 & 0.01 \\
\hline $\mathrm{CaO}$ & 0.09 & 0.08 & 0.04 & 0.05 & 0.05 & 0.08 & 0.08 & 0.06 \\
\hline $\mathrm{Na}_{2} \mathrm{O}$ & 0.03 & 0.10 & 0.06 & 0.06 & 0.34 & 0.17 & 0.11 & 0.30 \\
\hline $\mathrm{K}_{2} \mathrm{O}$ & 0.03 & 0.17 & 0.02 & 0.04 & 10.5 & 9.75 & 8.80 & 6.72 \\
\hline Total & 86.8 & 86.3 & 86.3 & 864 & 93.6 & 96.7 & 89.1 & 90.5 \\
\hline Si apfu & 4.055 & 4.033 & 4.024 & 4.050 & 6.381 & 6.370 & 6.525 & 6.460 \\
\hline $\mathrm{Al}$ & 3.883 & 3.891 & 3.953 & 3.915 & 5.330 & 5.343 & 5.231 & 5.490 \\
\hline $\mathrm{Ti}$ & 0.001 & 0,000 & 0.000 & 0.001 & 0.002 & 0.020 & 0.011 & 0.002 \\
\hline $\mathrm{Cr}$ & 0.001 & 0.001 & 0.001 & 0.001 & 0.000 & 0.001 & 0.002 & 0.001 \\
\hline $\mathrm{Fe}^{3+}$ & 0.022 & 0.027 & 0.004 & 0.004 & & & & \\
\hline $\mathrm{Fe}^{2+}$ & & & & & 0.066 & 0.211 & 0.089 & 0.072 \\
\hline $\mathrm{Mg}$ & 0.018 & 0.031 & 0.006 & 0.006 & 0.215 & 0.144 & 0.173 & 0.135 \\
\hline $\mathrm{Mn}$ & 0.000 & 0.001 & 0.000 & 0.002 & 0.001 & 0.005 & 0.003 & 0.001 \\
\hline $\mathrm{Ca}$ & 0.008 & 0,007 & 0.004 & 0.005 & 0.007 & 0.011 & 0.012 & 0.009 \\
\hline $\mathrm{Na}$ & 0.003 & 0.008 & 0.010 & 0.010 & 0.089 & 0.042 & 0.030 & 0.078 \\
\hline $\mathbf{K}$ & 0.002 & 0.009 & 0.002 & 0.004 & 1807 & 1.624 & 1.575 & 1,164 \\
\hline \multirow[t]{5}{*}{0} & 14.0 & $\$ 4.0$ & 14.0 & 14.0 & 22.0 & 22.0 & 22.0 & 22,0 \\
\hline & Clinochlore & & Sudoite & & \multicolumn{4}{|c|}{ Magnesiofoitite } \\
\hline & DDH & MAC & DDH & HL20 & MAC & MAC & MAC & MAC \\
\hline & 2033 & 204 & 2033 & -88 & 110 & 110 & 110 & 121 \\
\hline & -587 & -227 & -313 & -443 & -443 & -444 & -453 & -345 \\
\hline $\mathrm{SiO}_{2} \mathrm{wt} \%$ & 33.3 & 39.2 & 37.7 & 36.7 & 37.9 & 37.1 & 37.1 & 38.2 \\
\hline $\mathrm{TiO}_{2}$ & 0.01 & 0.01 & 0.06 & 0.03 & 0.01 & 0.01 & 0.01 & 0.02 \\
\hline $\mathrm{Al}_{2} \mathrm{O}_{3}$ & 22.2 & 33.4 & 32.5 & 37.0 & 39.0 & 39.0 & 36.2 & 36.4 \\
\hline $\mathrm{Cr}_{2} \mathrm{O}_{3}$ & 0.02 & 0.01 & 0.01 & 0.02 & 0.03 & 0,07 & 0.37 & 0.09 \\
\hline FeOtt & 6.60 & 0.54 & 0.33 & 1.02 & 0.76 & 0.76 & 1.13 & 1.15 \\
\hline $\mathrm{MgO}$ & 25.4 & 10.4 & 14.7 & 7.48 & 7.37 & 7.71 & 7,36 & 7.71 \\
\hline $\mathrm{MnO}$ & 0.03 & 0.01 & 0.02 & 0.01 & 0.05 & 0.01 & 0.01 & 0.01 \\
\hline $\mathrm{CaO}$ & 0.16 & 0.24 & 0.16 & 0.19 & 0.17 & 0.24 & 0.12 & 0.14 \\
\hline $\mathrm{Na}_{2} \mathrm{O}$ & 0.11 & 0.23 & 0.04 & 0.77 & 0.49 & 0.44 & 0.71 & 0.75 \\
\hline $\mathrm{K}_{2} \dot{\mathrm{O}}$ & 0.05 & 1.33 & 0.92 & 0.06 & 0.02 & 0.01 & 0.02 & 0.02 \\
\hline $\mathrm{B}_{2} \mathrm{O}_{3}{ }^{*}$ & & & & & 11.1 & 11.0 & 10.7 & 10.9 \\
\hline $\mathrm{H}_{2} \mathrm{O}^{*}$ & & & & & 3.84 & 3.80 & 3.67 & 3.77 \\
\hline Total & 88.0 & 85.5 & 86.4 & 83.4 & 100.8 & 100.2 & 97.5 & 99.2 \\
\hline Si apfu & 6.233 & $6.993^{*}$ & $* * 6.690^{*}$ & $* 6.656 *$ & * 5.909 & 5.841 & 6.050 & 6.067 \\
\hline $\mathrm{Al}$ & 4.896 & 7.034 & 6.795 & 8.089 & 7.169 & 7.370 & 6.957 & 6.814 \\
\hline $\mathrm{Ti}$ & 0.001 & 0.001 & 0.009 & 0.005 & 0.001 & 0.001 & 0.001 & 0.003 \\
\hline $\mathrm{Cr}$ & 0.002 & 0.001 & 0.001 & 0.002 & 0.004 & 0.009 & 0.047 & 0.011 \\
\hline $\mathrm{Fe}$ & 1.032 & 0.096 & 0.054 & 0.178 & 0.099 & 0.100 & 0.154 & 0.153 \\
\hline $\mathrm{Mg}$ & 7.090 & 3.307 & 4.313 & 2.320 & 1.714 & 1.811 & 1.790 & 1.826 \\
\hline Mn & 0.004 & 0.001 & 0.003 & 0.001 & 0.006 & 0.001 & 0.001 & 0.001 \\
\hline $\mathrm{Ca}$ & 0.033 & 0.055 & 0.034 & 0.043 & 0.028 & 0.041 & 0.021 & 0.024 \\
\hline $\mathrm{Na}$ & 0.040 & 0 & 0 & 0 & 0.148 & 0.134 & 0.225 & 0.231 \\
\hline $\mathrm{K}$ & 0.011 & 0 & 0 & 0 & 0.004 & 0.002 & 0.004 & 0.004 \\
\hline B & & & & & 3.0 & 3.0 & 3.0 & 3.0 \\
\hline $\mathrm{OH}$ & & & & & 4.0 & 4.0 & 4.0 & 4.0 \\
\hline 0 & 28.0 & 28.0 & 28.0 & 28.0 & 29.0 & 29.0 & 29.0 & 29.0 \\
\hline
\end{tabular}

wt\%: weight percent; apfu: atoms per formula unit. $\mathbf{t}$ total iron content as $\mathrm{Fe}_{2} \mathrm{O}_{3}$; $\mathrm{tt}$ total iron content as $\mathrm{FeO} ;{ }^{*} \mathrm{~B}_{2} \mathrm{O}_{3}$ and $\mathrm{H}_{2} \mathrm{O}$ contents in magnesiofoitite calculated on the basis of stoichiometry ( $c f$. Hawthorne et al. 1999); ${ }^{* *}$ formulae of sudoite calculated after correction for illite contamination (cf. Percival \& Kodama 1989). polytypes prevail in the regional sandstones (see also Percival et al. 1993).

All of our illite separates (Fig. 2c) were taken from the alteration haloes associated with uranium mineralization (Table 1), because illite-bearing samples from other settings invariably contain other clay minerals (e.g., dickite in regional sandstones). Electron-microprobe analyses show that illite in the alteration haloes also varies widely in composition (e.g., 6 to $12 \mathrm{wt} \%$ $\mathrm{K}_{2} \mathrm{O}$; Table 2). Following Srodon \& Eberl (1984), all of our illite separates from the alteration haloes contain either $3 T$ or mixtures of $3 T$ and $2 M_{1}$ polytypes, consistent with the observations of Hoeve \& Quirt (1984a, b) and Percival et al. (1993). Also, our XRD analyses of ethylene-glycol-treated samples did not reveal any expansion or peak shifts, confirming the observation of Hoeve \& Quirt (1987) that smectite and mixed-layer clay minerals are conspicuously absent in the alteration haloes. The crystallinity (i.e., the Kübler index; Kübler 1964) of our illite separates varies from 0.58 to 1.67 (Table 1).

The SWIR spectra of illite have two diagnostic absorption peaks at the 1400 and $2200 \mathrm{~nm}$ regions (Fig. 5). The $1400 \mathrm{~nm}$ peak is derived from the $\mathrm{OH}$-overtone stretching vibration, and the $2200 \mathrm{~nm}$ absorption is related to the $\mathrm{Al}-\mathrm{OH}$ bending combined with $\mathrm{OH}$ stretching (Hauff et al. 1991, Masinter \& Lyon 1991). An additional peak at the $1900 \mathrm{~nm}$ region in some illite separates is related to adsorbed water. Hauff $e t$ al. (1991) and Masinter \& Lyon (1991) noted that the position, strength and asymmetry of the 1400 and $2200 \mathrm{~nm}$ peaks are functions of the illite composition and structural disorder. For example, Hauff et al. (1991) reported that the asymmetry of the $2200 \mathrm{~nm}$ peak, defined as the ratio of the left and right areas of this peak, increases with increase in crystallinity. Figure 6 shows that the asymmetry of the $2200 \mathrm{~nm}$ peak of the SWIR spectra of the Athabasca illite separates appears to correlate positively with the Kübler index, except that several outliers are also notable. Post \& Noble (1993) reported an influence on the position of the $2200 \mathrm{~nm}$ peak exerted by composition, and established a linear relationship between the $2200 \mathrm{~nm}$ band frequency and the $\mathrm{Al}$ content. Owing to the narrow range of the $\mathrm{Al}$ content of our illite separates, we could not evaluate this relationship. Also, no correlation has been observed between the K contents and the spectral features for the illite separates. Figure 5 also shows that the spectrum of an Athabasca $3 T$ illite is indistinguishable from that of a $2 M_{1}$ muscovite. This is most likely related to the relatively low resolution of the PIMA-II instrument, because $3 T$ illite and $2 M_{1}$ muscovite have distinct FTIR spectra (Zhang 2000).

\section{Chlorite-group minerals}

The dominant chlorite-group mineral in the Athabasca Basin is sudoite (Fig. 2d), whereas clinochlore is gener- 


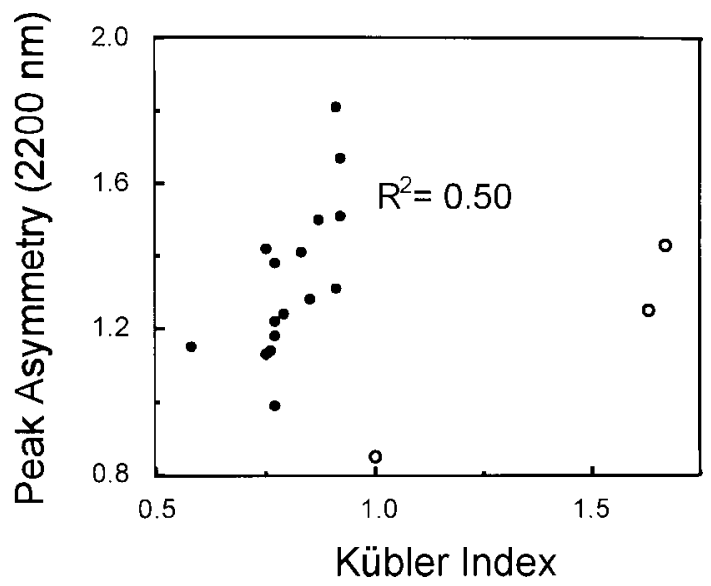

FIG. 6. Plot of the asymmetry of the $2200 \mathrm{~nm}$ peak versus the Kübler index for the $3 T$ Athabasca illite separates. Correlation coefficient calculated without the outliers (open circles).

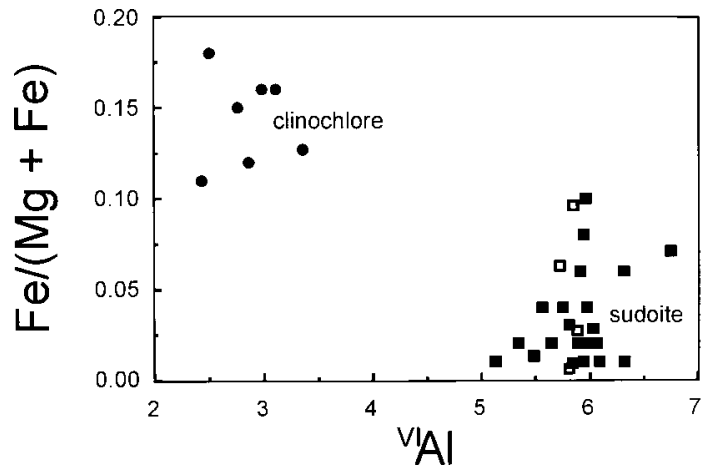

FIG. 7. Plot of $\mathrm{Fe} /(\mathrm{Mg}+\mathrm{Fe})$ versus ${ }^{\mathrm{VI}} \mathrm{Al}$ illustrating the chemical compositions of clinochlore (solid circles) and sudoite (solid squares) in the Athabasca Basin. Also shown are compositions of sudoite in the literature (open squares; data from Percival \& Kodama 1989).

ally restricted to basement rocks (Hoeve \& Quirt 1984a, Percival \& Kodama 1989). XRD analyses and EPMA reveal that all of our chlorite separates are sudoite-dominant (II $b$ polytype, Bailey 1988), except for one, which is clinochlore-rich (Tables 1, 2).

The Athabasca sudoite varies significantly in composition, particularly in $\mathrm{Al}$ (Table 2, Fig. 7). Also, all samples of sudoite have considerable amounts of $\mathrm{K}$ and $\mathrm{Na}$, which are attributable to illite contamination (Percival \& Kodama 1989). The proportion of admixed illite, estimated by assigning all of the $\mathrm{K}$ and $\mathrm{Na}$ con-

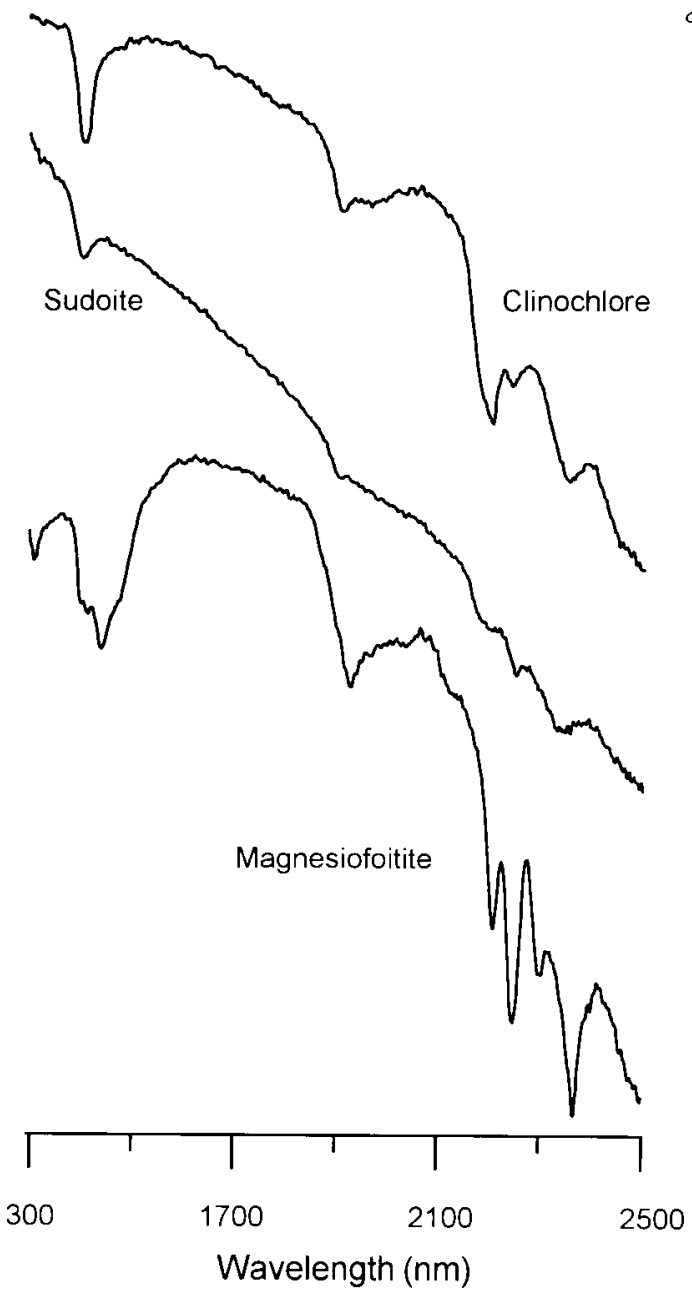

FIG. 8. Comparison of the SWIR spectra of Athabasca clinochlore, sudoite and magnesiofoitite.

tents to $(\mathrm{K}, \mathrm{Na}) \mathrm{Al}_{2}\left(\mathrm{Si}_{3} \mathrm{Al}\right) \mathrm{O}_{10}(\mathrm{OH})_{2}$ to represent a minimum value (Percival \& Kodama 1989), ranges from 5 to 20 mol.\%. Percival \& Kodama (1989) attributed this intimate association of sudoite with illite to the formation of the former at the expense of the latter. It is noteworthy that the formulae of the sudoite after correction for illite contamination (Table 2) still deviate significantly from the ideal composition $\left[\left(\mathrm{Al}_{6} \mathrm{Mg}_{4}\right)\left(\mathrm{Si}_{6} \mathrm{Al}_{2}\right) \mathrm{O}_{20}\right.$ $(\mathrm{OH})_{16}$; Lin \& Bailey 1985], but an apparent compositional gap between sudoite and clinochlore remains (Fig. 7).

In the SWIR reflectance spectra, sudoite is characterized by absorption peaks at the 1400, 2190, 2250 and $2340 \mathrm{~nm}$ regions, whereas clinochlore does not show an absorption at $2190 \mathrm{~nm}$ (Fig. 8). Several separates of 
sudoite have dark colors and hence lower peak-to-noise ratios than those of other clay minerals (e.g., kaolinite and dickite) in the SWIR reflectance spectra.

The absorption bands of sudoite at 2190, 2250, and $2300 \mathrm{~nm}$ correspond to $\mathrm{Al}-\mathrm{OH}$ bending plus $\mathrm{OH}$-overtone stretching, $\mathrm{Fe}-\mathrm{OH}$ bending and $\mathrm{OH}$-overtone stretching, and $\mathrm{Mg}-\mathrm{OH}$ bending and $\mathrm{OH}$ stretching, respectively (King \& Clark 1989, Prieto et al. 1991). The Athabasca sudoite has limited ranges in $\mathrm{Fe}$ and $\mathrm{Mg}$ contents (Table 2), which do not permit a quantitative evalu- ation of relationships with the 2250 and $2300 \mathrm{~nm}$ peaks (e.g., Shirozu 1985). In Figure 9, the $\sim 2190 \mathrm{~nm}$ peak seems to shift systematically with total Al, suggesting a possible influence of $\mathrm{Al}$ content on this absorption band (see also Shirozu 1985). However, one difficulty in the application of SWIR reflectance spectroscopy for quantitative analysis of the Athabasca sudoite for $\mathrm{Al}$ is the intimate association of this mineral with other Al-rich clay minerals (e.g., illite and kaolinite; Fig. 9).

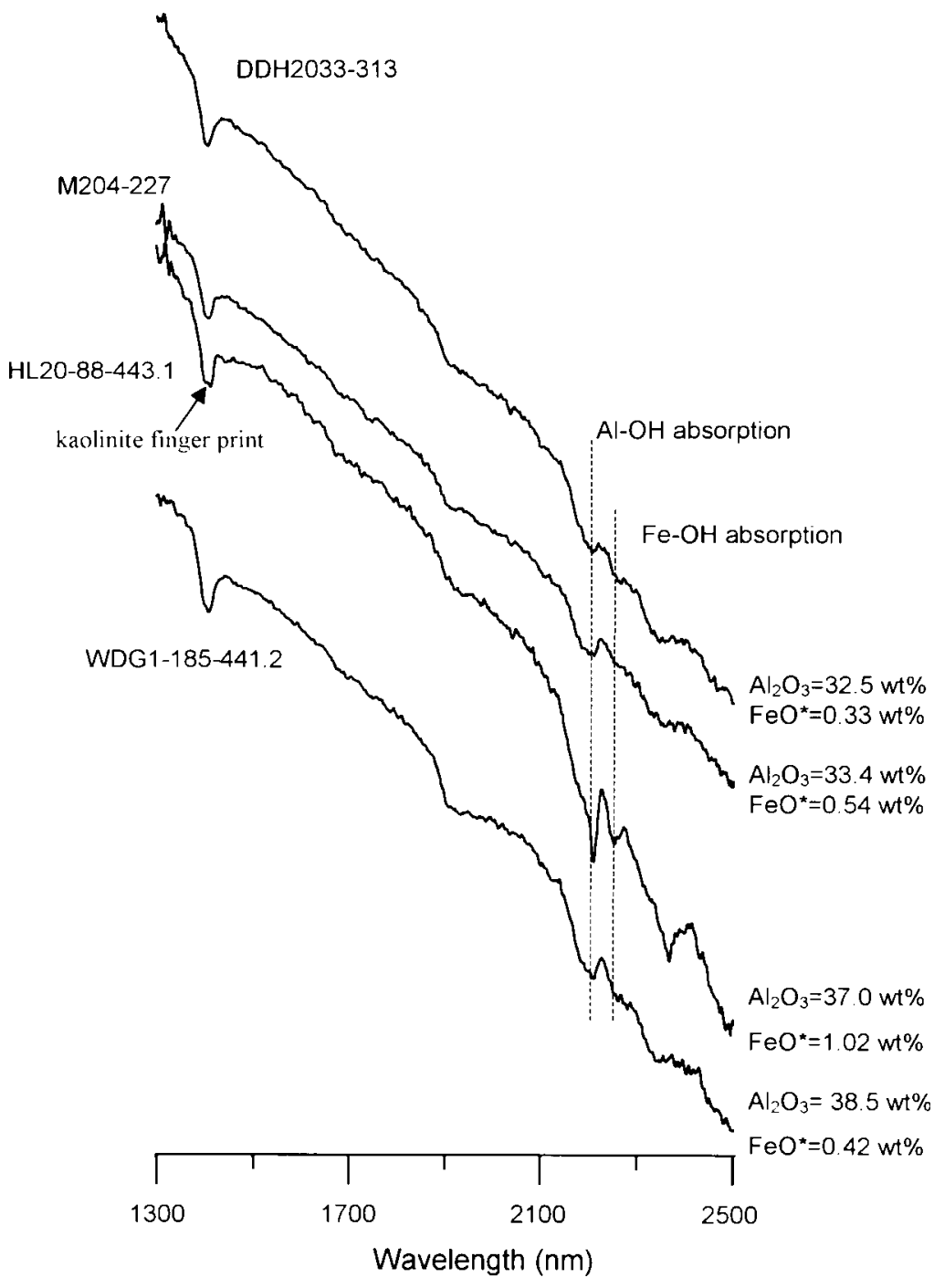

FIG. 9. The SWIR spectra of four Athabasca sudoite separates illustrating the variations of the $2190 \mathrm{~nm}$ and $2250 \mathrm{~nm}$ peaks with the $\mathrm{Al}_{2} \mathrm{O}_{3}$ and total $\mathrm{FeO}(\mathrm{FeO} *)$ contents, respectively. Also shown is an apparent "fingerprint" of kaolinite in sample HL20-88443.1 . 


\section{Tourmaline-group minerals}

Tourmaline-group minerals have long been reported in and around several Athabasca uranium deposits (e.g., Quirt et al. 1991). Two distinct types of tourmaline are reported (Kotzer \& Kyser 1995, Fayek \& Kyser 1997): detrital dravite-schorl and hydrothermal tourmaline. Our study focused on the latter; it occurs as essentially monomineralic aggregates of acicular crystals (Figs. 2e, f) as infillings in breccias and late fractures. The hydrothermal tourmaline deviates only slightly from the ideal formula of $\square\left(\mathrm{Mg}_{2} \mathrm{Al}\right) \mathrm{Al}_{6}\left(\mathrm{Si}_{6} \mathrm{O}_{18}\right)\left(\mathrm{BO}_{3}\right)_{3}(\mathrm{OH})_{4}$ ( $\square$ : vacancy; Table 2), corresponding to the newly established magnesiofoitite (Hawthorne et al. 1999). The $\delta \mathrm{D}$ values of three magnesiofoitite separates are $-92,-89$ and $-80 \%$, respectively (Table 1), within the range reported by Kotzer \& Kyser (1995). The SWIR spectra of the Athabasca magnesiofoitite are characterized by wellresolved absorption bands at the 2100 to $2500 \mathrm{~nm}$ region (Fig. 8).

\section{The SWIR Spectra of Artificial Mixtures}

The availability of appropriate mineral standards of the same particle size and similar crystallinity and composition is of crucial importance to the application of infrared spectroscopic methods for quantitative analysis of mixtures (e.g., Sunshine \& Pieters 1993, Russell $\&$ Fraser 1994). The alteration assemblages in the Athabasca Basin are composed of clay minerals of mainly $\leq 2 \mu \mathrm{m}$, an ideal size to ensure maximum absorption and minimum scattering by the samples (Russell \& Fraser 1994). Previous investigators (Hoeve \& Quirt 1984a, b, Percival et al. 1993) have shown that clay minerals in the Athabasca Basin vary widely in crystallinity (e.g., kaolinite) and chemical composition (e.g., illite and sudoite). Therefore, our selection of mineral standards took these variables into account. For example, kaolinite from Montana was selected for its Hinckley index of 1.02, which is intermediate with respect to the range observed in the Athabasca suite (Table 1). Also, a $2 M_{1}$ muscovite was used as an analogue for illite for the following two reasons: 1) similarity in their SWIR spectra (Fig. 5) and 2) scarcity of high-purity illite.

\section{Binary mixtures}

Analyses of the artificial quartz - kaolinite and quartz - dickite mixtures revealed that the spectral features such as peak positions and relative intensities do not vary with the abundance of quartz, except for a minor decrease in the overall signals when the amount of quartz exceeds $98 \mathrm{wt} . \%$. Also, the mixtures of only 1 wt.\% kaolinite and dickite yielded well-resolved SWIR spectra, supporting observations from natural samples that PIMA II can readily detect clay minerals at abundances of $\sim 1 \mathrm{wt} \%$, and possibly much lower for sand- stone samples containing essentially a single clay mineral.

Figure 10 shows how the spectral features such as intensity, peak position and slope vary systematically with the mineral abundance in the kaolinite - dickite mixtures. In particular, the spacing between the two peaks of the $\sim 1400 \mathrm{~nm}$ doublet decreases with increase in the abundance of kaolinite, whereas the spacing between the two peaks at the $2200 \mathrm{~nm}$ region increases with increase in kaolinite. Similarly, the spectra of the

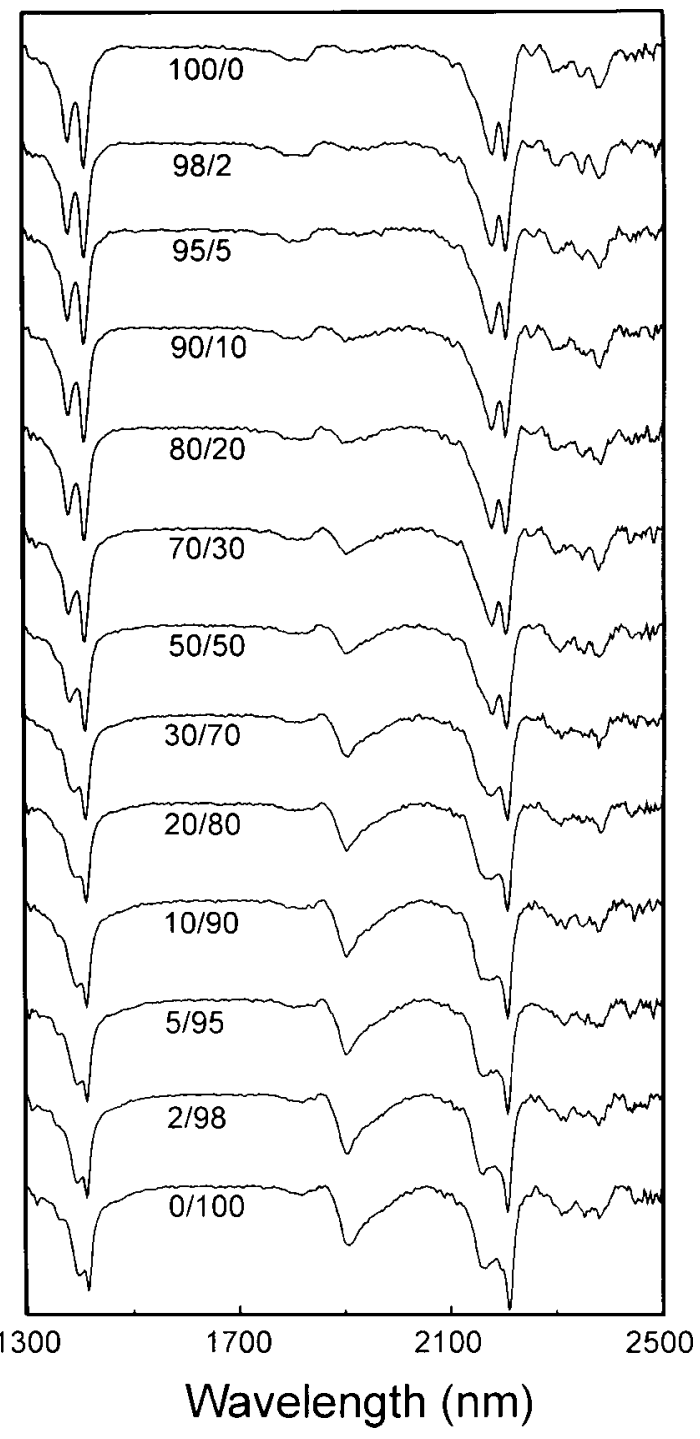

FIG. 10. SWIR reflectance spectra for the kaolinite - dickite mixtures to illustrate the systematic variations between the spectral features and mineral abundances. 
kaolinite - muscovite mixtures also vary systematically with mineral abundance, as do those of the dickite muscovite and sudoite - muscovite mixtures (Zhang 2000).

In his empirical method, Earle (1994) used spectral parameters such as $\mathrm{dR}_{14}$ and $\mathrm{dR}_{22}$, which represent the differences in relative intensities at the 1400 and 2200 $\mathrm{nm}$ regions $\left(\mathrm{dR}_{14}=\mathrm{R}_{1402}-\mathrm{R}_{1390}\right.$ and $\mathrm{dR}_{22}=\mathrm{R}_{2194}-$ $R_{2180}$ ), and assumed them to be linear with mineral abundances. Application of these parameters to the bi- nary mixtures yielded significant deviations from linearity for both the dickite - muscovite (Fig. 11a) and sudoite - muscovite mixtures. Therefore, the assumption of linearity (Earle 1994) is not valid for the spectral parameters as defined. Accordingly, we modified the $\mathrm{dR}_{14}$ parameter to: $\mathrm{dR}_{14}=\mathrm{R}_{1402}-\mathrm{R}_{1394}$. Figures $11 \mathrm{~b}$ and $11 \mathrm{c}$ show that the abundances of dickite and kaolinite (and muscovite) in the dickite - muscovite and kaolinite - muscovite mixtures correlate linearly with the modified $\mathrm{dR}_{14}$ parameter. Figure $11 \mathrm{~d}$ shows that the
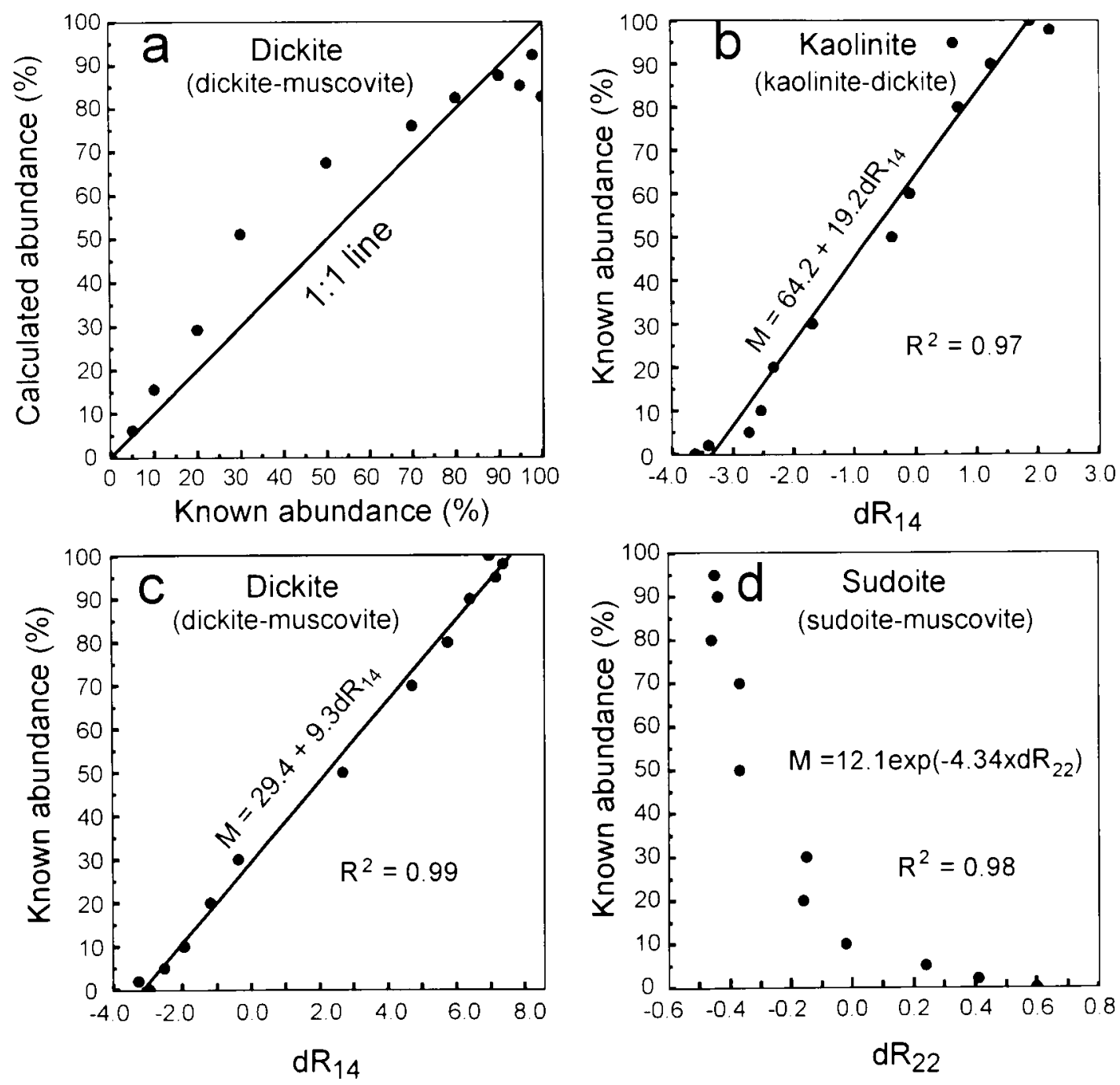

FIG. 11. Plots illustrating the results from binary mixtures: a) comparison of the abundances of dickite calculated from the empirical method of Earle (1994) with the known values in the dickite - muscovite mixtures. b) $\mathrm{dR}_{14}$ versus the abundance of kaolinite in the kaolinite - muscovite mixtures. c) $\mathrm{dR}_{14}$ versus the abundance of dickite in the dickite - muscovite mixtures. d) $\mathrm{dR}_{22}$ versus the abundance of sudoite in the sudoite - muscovite mixtures. Numerical relationships in b), c) and d) were obtained by least-squares regression. 
abundance of sudoite in the sudoite - muscovite mixtures has a well-defined curvilinear relationship with a modified $\mathrm{dR}_{22}$ parameter $\left(\mathrm{dR}_{22}=\mathrm{R}_{2238}-\mathrm{R}_{2230}\right)$.

\section{Ternary mixtures}

The two ternary mixtures, which represent two common types of alteration assemblages associated with the uranium deposits (i.e., illite - kaolinite - sudoite at Key Lake and illite - sudoite - magnesiofoitite at McArthur River) in the Athabasca Basin, were used to test the numerical relationships from the binary mixtures. Figure 12a shows that there is excellent agreement between the calculated and known abundances of kaolinite in the muscovite - kaolinite - sudoite mixtures. Similarly, the calculated abundance of kaolinite in the muscovite kaolinite - magnesiofoitite mixtures is in excellent agreement with its known abundance (Fig. 12b). Also, the calculated and known abundances of sudoite in the muscovite - kaolinite - sudoite mixtures are in general agreement, albeit somewhat scattered (Fig. 12c). Two possible causes for this scatter are: 1) sample heterogeneity in the starting materials (i.e., variable amounts of illite associated with sudoite), and 2) poor reflectance of sudoite because of its dark color.

Precision, accuracy and detection limits of the SWIR method for quantitative analysis of clay minerals

Selected artificial mixtures of the binary and ternary experiments have also been used to evaluate the precision, accuracy and detection limit of the empirical SWIR method for quantitative analysis of clay minerals. The results of these analyses show that these parameters are all related to a number of variables, such as the overall reflectance of a given sample, and the total abundance of clay minerals in it. For example, dark samples have a low reflectance, resulting in poorly resolved spectra, with a high background and hence low precision and high detection-limits. Similarly, samples with a low abundance $(\leq 2 \mathrm{wt} \%)$ of total clay minerals also have high noise-to-signal ratios in the SWIR spectra, and hence reduced precision and accuracy. Repeated analyses of selected mixtures, used to demonstrate the precision of the SWIR method, show that the relative standard deviations (RSD) are between 5 to $10 \%$ for abundances of clay minerals above $10 \mathrm{wt} \%$, but increase to as much as $20 \%$ for abundances below $10 \mathrm{wt} \%$. The accuracy of the SWIR method has been evaluated by comparison with known abundances. The differences between those from the SWIR method and known abundances are generally within 5 to $10 \mathrm{wt} \%$, except for some analyses of sudoite (Fig. 12). Detection limits (three standard deviations of the background) have been estimated by analysis of quartz - kaolinite (89/11) and quartz - dickite (90/10) mixtures to be $\sim 5 \mathrm{wt} \%$ in relative abundance (i.e., $\sim 0.5 \mathrm{wt} \%$ in absolute abundance for samples containing $\sim 10 \mathrm{wt} \%$ total clay minerals).

\section{Discussion AND CONCLUSIONS}

This study shows that SWIR reflectance spectroscopy is a powerful technique for the identification of clay minerals in alteration assemblages (see also Hauff et al. 1991). The use of infrared spectroscopy for the identification and characterization of minerals in laboratories is not new (e.g., Farmer 1974, Hunt \& Ashley 1979). The main advantage of the SWIR technique is
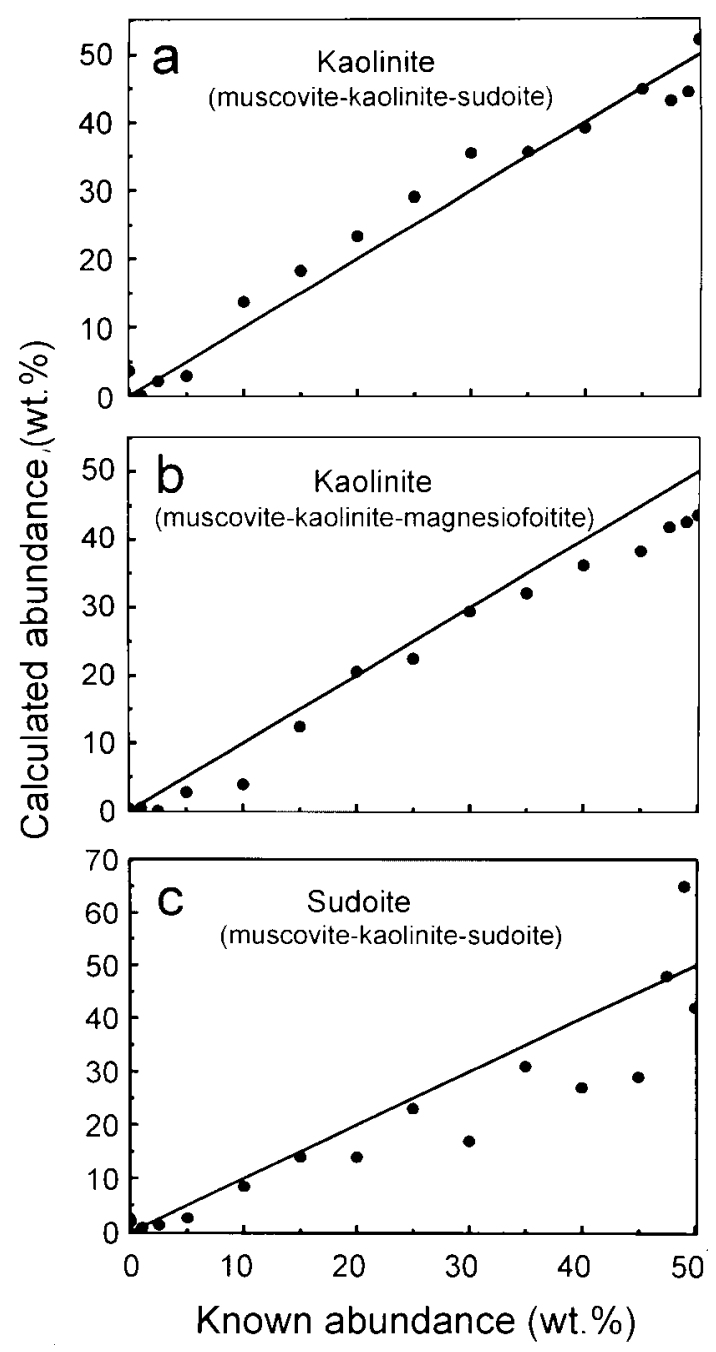

FIG. 12. Results of ternary artificial mixtures showing calculated versus known abundances of a) kaolinite in the muscovite - kaolinite - sudoite mixtures, b) kaolinite in the muscovite - kaolinite - magnesiofoitite mixtures, and c) sudoite in the muscovite - kaolinite - sudoite mixtures. Here, the calculated abundances were obtained by using the new numerical relationships derived from the binary mixtures of this study (see Fig. 11). 
its portability, which makes it possible to characterize alteration assemblages in the field or at drilling sites, so that geologists can quickly modify their exploration strategies in light of new information available to them in the field. Moreover, we find that SWIR reflectance spectroscopy is useful in providing such information as crystallinity and paragenesis of kaolinite in the Athabasca Basin. For example, we established a "14SP Index" for quantitative analysis of the crystallinity of kaolinite and showed that kaolinite in different geological settings of the Athabasca Basin has distinct values of crystallinity. Therefore, SWIR reflectance spectroscopy is a potentially useful paragenetic indicator. However, attempts to use SWIR reflectance spectroscopy for structural and compositional analysis of other clay minerals [e.g., polytypism and crystallinity of illite (Figs. 5,6) and the Al content of sudoite (Fig. 9)] were inconclusive, owing primarily to the common occurrence of impurities.

The widespread presence of dickite in the Athabasca sandstones away from the alteration haloes, first suggested by Earle et al. (1996) on the basis of SWIR spectra, has been confirmed by a combined SEM, XRD, EPR, EMPA and SWIR analysis of this study. Moreover, a follow-up study (Wasyliuk, Pan \& T.K. Kyser, in prep.) has revealed the local presence of dickite in some alteration haloes and late cavities in the Athabasca Basin. Only sporadic occurrences of dickite have been reported for the Athabasca Basin in the past (e.g., Hoeve \& Quirt 1984a). This lack of appreciation for the widespread presence of dickite in this basin is undoubtedly attributable to the fact that this mineral is almost identical to kaolinite in conventional XRD analysis in the range from 3 to $65^{\circ} 2 \theta(\mathrm{Cu} K \alpha$ radiation; Brindley 1980 , Giese 1988).

Hydrothermal tourmaline in spatial association with unconformity-type uranium deposits (e.g., Key Lake and McArthur River) in the Athabasca Basin has long been recognized, but was referred to "dravite" or "alkali-free dravite" (e.g., Quirt et al. 1991, Kotzer et al. 1993). We show that the hydrothermal tourmaline at the Key Lake and McArthur River deposits is magnesiofoitite ( $c f$. Hawthorne et al. 1999). Therefore, these deposits represent two new localities for this newly established mineral species. Moreover, the Athabasca magnesiofoitite is unusual in its local abundance and, together with sudoite, represents a pervasive Mg-rich hydrothermal alteration that has been suggested to be broadly coeval with the uranium mineralization (Fayek \& Kyser 1997). Stable isotopic analyses on magnesiofoitite and coexisting quartz and illite from the Athabasca Basin by Kotzer et al. (1993) reveal that this mineral formed at temperatures between 170 and $220^{\circ} \mathrm{C}$.

The preparation of artificial mixtures showed that SWIR reflectance spectroscopy is a powerful technique for quantitative analysis of clay minerals. For example, we have shown SWIR reflectance spectroscopy to be capable of detecting and identifying clay minerals at abundances as low as $1 \mathrm{wt} \%$ or possibly lower in samples containing a single clay mineral, making the SWIR technique in analysis of clay-poor samples superior to conventional XRD methods that require mineral abundances above 5\%. Also, numerical relationships between spectral features (i.e., $\mathrm{dR}_{14}$ and $\mathrm{dR}_{22}$ ) and mineral abundances have been obtained from selected binary mixtures and have been applied successfully to the improvement of an empirical method for quantitative analysis of clay minerals. The estimated precision and accuracy of the improved empirical method are both between 5 and $10 \%$, depending on the total abundance of clay minerals, and are comparable to estimates derived from conventional XRD methods (Brindley 1980, Reynolds 1989). The detection limits for samples that contain assemblages of clay minerals are approximately $5 \mathrm{wt} \%$ in relative abundance, considerably better than those of XRD methods (Brindley 1980, Reynolds 1989). It should be pointed out, however, that the abundances of individual clay minerals in the sandstone samples, as obtained with the SWIR method, are relative values (i.e., quartz not included), and thus different from those obtainable from the XRD methods (e.g., Reynolds 1989, Raudsepp et al. 1999). These relative abundances are particularly useful for characterizing the clay-mineraldominant alteration haloes and can be converted to absolute values for samples in which the total abundance of clay minerals is known independently.

\section{ACKNOWLEDGEMENTS}

We thank H. Kodama and an anonymous referee for constructive criticisms and helpful suggestions, and R.F. Martin for editorial assistance. We also thank A. Mermut of the Department of Soil Sciences, D. Quirt of the Saskatchewan Research Council, and V. Sopuck of the Cameco Corporation for many stimulating discussions and helpful suggestions throughout the course of this study, and T. Bonli (EMPA, SEM and XRD), N. Chen (EPR), J.-L. Du (FTIR), B. Novakovski (polished thin sections and Pyrex plugs) and D. Pezderic (hydrogen isotope) for analytical assistance. Financial support for this study was provided by an NSERC-Industry (Cameco) Collaborative Research and Development Grant.

\section{REFERENCES}

Artioli, G., Bellotto, M., Gualtieri, A. \& Pavese, A. (1995): Nature of structural disorder in natural kaolinites: a new model based on computer simulation of powder diffraction data and electrostatic energy calculation. Clays Clay Minerals 43, 438-445.

BAILEY, S.W. (1988): Chlorites: structures and crystal chemistry. In Hydrous Phyllosilicates (Exclusive of Micas) (S.W. Bailey, ed.). Rev. Mineral. 19, 347-403.

BARNES, H.L., ed. (1997): Geochemistry of Hydrothermal Ore Deposits (3rd ed.). John Wiley \& Sons, New York, N.Y. 
BRINDLEY, G.W. (1980): Quantitative X-ray mineral analysis of clays. In Crystal Structures of Clay Minerals and their X-Ray Identification. Mineral. Soc., Monogr. 5, 411-438.

Kao, Chih-Chun, Harrison, J.L., Lipsicas, M. \& RAYTHATHA, R. (1986): Relation between structural disorder and other characteristics of kaolinites and dickites. Clays Clay Minerals 34, 239-249.

Delineau, T., Allard, T., Muller, J.P., Barres, O., Yvon, J. \& CASES, J.M. (1994): FTIR reflectance vs EPR studies of structural iron in kaolinites. Clays Clay Minerals 42, 308320.

EARLE, S. (1994): Application of reflectance spectrometry to analysis of Manitou Falls Formation samples. Unpub. Rep., Cameco Co., Saskatoon, Saskatchewan.

Wheatley, K. \& Wasyliuk, K. (1996): Application of reflectance spectroscopy to the assessment of alteration mineralogy in the Key Lake uranium deposit, Saskatchewan. In Proc. Minexpo '96 Symp. (K.E. Ashton \& C. Harper, eds.). Sask. Geol. Mineral. Explor., Spec. Publ. 14, 109-123.

FARMER, V.C. (1974): The Infrared Spectra of Minerals. Mineralogical Society, London, U.K. (331-363).

FAYEK, M. \& KYSER, T.K. (1997): Characterization of multiple fluid-flow events and rare-earth element mobility associated with formation of unconformity-type uranium deposits in the Athabasca Basin, Saskatchewan. Can. Mineral. 35, 627-658.

Fouques, J.P., Fowler, M., KnipPing, H.D. \& Schimann, K. (1986): Le gisement d'uranium de Cigar Lake: découverte et caractéristiques générales. Can. Inst. Mining Metall., Bull. 79(886), 70-82.

Gaite, J.M., ErmakofF, P., Allard, T. \& Muller, J.P. (1997): Paramagnetic $\mathrm{Fe}^{3+}$ : a sensitive probe for disorder in the kaolinite. Clays Clay Minerals 45, 496-505.

GIESE, R.F., JR. (1988): Kaolinite minerals: structures and stabilities. In Hydrous Phyllosilicates (Exclusive of Micas) (S.W. Bailey, ed.). Rev. Mineral. 19, 29-66.

Hauff, P., Kruse, F.A., Madrid, R., Fraser, S., Huntington, J., JONES, M. \& WATTERS, S. (1991): Illite crystallinity case histories using X-ray diffraction and reflectance spectroscopy to define ore host environments. In Proc. Eighth Thematic Conf. on Geologic Remote Sensing (Denver), 447-458.

Hawthorne, F.C., Selway, J.B., Kato, A., Matsubara, S., Shimizu, M., GricE, J.D. \& VAJDAK, J. (1999): Magnesiofoitite, $\square\left(\mathrm{Mg}_{2} \mathrm{Al}\right) \mathrm{Al}_{6}\left(\mathrm{Si}_{6} \mathrm{O}_{18}\right)\left(\mathrm{BO}_{3}\right)_{3}(\mathrm{OH})_{4}$, a new alkalideficient tourmaline. Can. Mineral. 37, 1439-1443.

HINCKLEY, D.N. (1963): Variability in "crystallinity" values among the kaolin deposits of the Coastal Plain of Georgia and South Carolina. Clays Clay Minerals 11, 229-235.
Hoeve, J. \& QuiRT, D. (1984a): Mineralization and host rock alteration in relation to clay mineral diagenesis and evolution of the Middle-Proterozoic, Athabasca Basin, Northern Saskatchewan. Sask. Res. Council, Tech. Rep. 157.

$\&$ (1984b): Host rock alteration and its application as an ore guide at the Midwest Lake uranium deposit, northern Saskatchewan. Can. Inst. Mining Metall., Bull. 77(868), 63-72.

$\&$ (1987): A stationary redox front as a critical factor in the formation of high-grade, unconformitytype uranium ores in the Athabasca Basin, Saskachewan, Canada. Bull. Minéral. 110, 157-171.

Hunt, G. \& Ashley, R.P. (1979): Spectra of altered rocks in the visible and near infrared. Econ. Geol. 74, 1613-1629.

Jambor, J.L. \& Delabio, R.N. (1978): Distribution of hydrothermal clay minerals in the Valley Copper porphyry deposit, Highland Valley, British Columbia. Geol. Surv. Can., Pap. 77-9, 1-21.

Johnston, C.T., Helsen, J., Schoonheydt, R.A., Bish, D.L. \& AGNEw, S.F. (1998): Single-crystal Raman spectroscopy study of dickite. Am. Mineral. 83, 75-84.

KING, T.V.V. \& CLARK, R.N. (1989): Spectral characteristics of chlorites and $\mathrm{Mg}$-serpentines using high-resolution reflectance spectroscopy. J. Geophys. Res. 94, 13,997-14,008.

Kotzer, T.G. \& Kyser, T.K. (1995): Petrogenesis of the Proterozoic Athabasca Basin, northern Saskatchewan, Canada, and its relation to diagenesis, hydrothermal uranium mineralization and paleohydrogeology. Chem. Geol. 120, $45-89$.

KING, R.W. \& KERRICH, R. (1993): An empirical oxygen- and hydrogen-geothermometer for quartz-tourmaline and tourmaline-water. Geochim. Cosmochim. Acta 57, 3421-3426.

KÜBLER, B. (1964): Les argiles, indicateurs du metamorphisme: Rev. Inst. France Pétrol. 19, 1093-1112.

Kyser, T.K., Hiatt, E., Renac, C., Durocher, K. \& Deckert, K. (2000): Diagenetic fluids in Paleo- and MesoProterozoic sedimentary basins and their implications for long protracted fluid histories. In Fluids and Basin Evolution (T.K. Kyser, ed.). Mineral. Assoc. Can., Short Course Vol. 28, 225-262.

Lin, Cheng Yi \& Bailey, S.W. (1985): Structural data for sudoite. Clays Clay Minerals 33, 410-414.

MacDonald, C. (1985): Mineralogy and geochemistry of the sub-Athabasca regolith near Wollaston Lake. In Geology of Uranium Deposits (T. Sibbald \& W. Petruk, eds.). Can. Inst. Mining Metall., Spec. Vol. 32, 155-158.

MASINTER, R.A. \& LYON, R.J.P. (1991): Spectroscopic confirmation of increasing illite ordering with hydrothermal 
alteration of argillaceous ore in the Gold Bar Mine, Eureka CO, Nevada. In Proc. Eighth Thematic Conf. on Geologic Remote Sensing (Denver), 563-571.

McCready, A.J., Annesley, I.R., PARnell, J. \& Richardson, L.R. (1999) The uranium - carbonaceous matter association, McArthur River, Canada. In Mineral Deposits: Processes to Processing (C.J. Stanley et al., eds.). Balkema, Rotterdam, The Netherlands (251-254).

McMillan, P.F. \& Hofmeister, A.M. (1988): Infrared and Raman spectroscopy. In Spectroscopic Methods in Mineralogy and Geology (F.C. Hawthorne, ed.). Rev. Mineral. 18, 99-159.

MeHRA, O.P. \& JACKSON, M.L. (1960): Iron oxide removal from soils and clays by a dithionite-citrate system buffered with sodium bicarbonate. Clays Clay Minerals, Proc. 7 th Nat. Conf., 317-327.

Mosser, C., Boudeulle, M., Weber, F. \& Pacquet, A. (1996): Ferriferous and vanadiferous kaolinites from the hydrothermal alteration halo of the Cigar Lake uranium deposit (Canada). Clay Minerals 31, 291-299.

Percival, J.B., Bell, K. \& Torrance, J.K. (1993): Clay mineralogy and isotope geochemistry of the alteration halo at the Cigar Lake uranium deposits. Can. J. Earth Sci. 30, 689-704.

\& Kodama, H. (1989): Sudoite from Cigar Lake, Saskachewan. Can. Mineral. 27, 633-641.

PlanÇON, A. \& TChOUBAR, C. (1977): Determination of structural defects in phyllosilicates by X-ray powder diffraction. II. Nature and proportion of defects in natural kaolinites. Clays Clay Minerals 25, 436-450.

Post, J.L. \& NoBle, P.N. (1993): The near-infrared combination band frequencies of dioctahedral smectites, micas, and illites. Clays Clay Minerals 41, 639-644.

Prieto, A.C., Dubessy, J. \& Cathelineau, M. (1991): Structure-composition relationships in trioctahedral chlorites: a vibrational spectroscopy study. Clays Clay Minerals 39, 531-539.

Quirt, D.H., Kotzer, T.G. \& Kyser, T.K. (1991): Tourmaline, phosphate minerals, zircon and pitchblende in the Athabasca Group: Maw Zone and McArthur River areas, Saskatchewan. Sask. Geol. Surv., Misc. Rep. 91-4, 181-191.

RAMAEKERS, P. (1981): Hudsonian and Helikian basins of the Athabasca region, northern Saskatchewan. Geol. Surv. Can., Pap. 81-10, 219-233.
Raudsepp, M., PANI, E. \& DipPle, G.M. (1999): Measuring mineral abundance in skarn. I. The Rietveld method using X-ray powder-diffraction data. Can. Mineral. 37, 1-15.

REYNOLDS, R.C. (1989): Principles and techniques of quantitative analysis of clay minerals by X-ray powder diffraction. In Quantitative Mineral Analysis of Clays (D.R. Pevear \& F.A. Mumpton, eds.). The Clay Mineral Society, Evergreen, Colorado (4-36).

Rusinova, O.V., Piloyan, G.O., Rusinov, V.L., Samotoin, N.D. \& Fedotov, A.F. (1974): Diagnostics of nacrite. Trudy Central Inst. Geol. Res. USSR (CNIGRI) 112, 11-28 (in Russ.).

Russell, J.D. \& Fraser, A.R. (1994): Infrared methods. In Clay Mineralogy: Spectroscopic and Chemical Determinative Methods (M.J. Wilson, ed.). Chapman \& Hall, London, U.K. (11-67).

SHIROZU, H. (1985): Infrared spectra of trioctahedral chlorites in relation to chemical composition. Clay Sci. 6, 167-176.

Środón, J. (1980): Precise identification of illite/smectite interstratifications by X-ray powder diffraction. Clays Clay Minerals 28, 401-411.

\& EBERL, D.D. (1984): Illite. In Micas (S.W. Bailey, ed.). Rev. Mineral. 13, 495-544.

Sunshine, J.M. \& Pieters, C.M. (1993): Estimating modal abundances from the spectra of natural and laboratory pyroxene mixtures using the modified Gaussian model. $J$. Geophys. Res. 98, 9075-9087.

Wilson, M.R. \& Kyser, T.K. (1987): Stable isotope geochemistry of alteration associated with the Key Lake uranium deposit, Canada. Econ. Geol. 82, 1540-1557.

Zhang, GuAngyu (2000): Characterization of Clay Minerals in the Athabasca Basin using shortwave infrared (SWIR) reflectance spectroscopy. M.Sc. thesis, Univ. Saskatchewan, Saskatoon, Saskatchewan.

Zotov, A., Mukhamet-Galeev, A. \& Schott, J. (1998): An experimental study of kaolinite and dickite relative stability at $150-300^{\circ} \mathrm{C}$ and the thermal properties of dickite. Am. Mineral. 83, 516-524.

Received January 6, 2001, revised manuscript accepted August 2, 2001. 